\title{
Space-use strategy affects energy requirements in Barents Sea polar bears
}

\author{
Marie-Anne Blanchet ${ }^{1,2, *}$, Jon Aars ${ }^{1}$, Magnus Andersen $^{1}$, Heli Routti ${ }^{1}$ \\ ${ }^{1}$ Norwegian Polar Institute, Fram Centre, Tromsø 9296, Norway \\ ${ }^{2}$ Norwegian College of Fishery Science, UiT The Arctic University of Norway, Tromsø 9219, Norway
}

\begin{abstract}
Polar bears Ursus maritimus are currently facing rapid environmental changes with loss of sea ice and shifts in their prey distribution. Two distinct ecotypes exist in the Barents Sea, where sea ice is decreasing at the highest rate in the Arctic. Coastal bears remain within the Archipelago of Svalbard year-round, whereas offshore bears follow the marginal ice zone (MIZ). We explored these 2 ecotypes' habitat use, activity and energy needs as well as seasonal variation within these parameters. During the period from 2011-2018, adult female polar bears were equipped with GPS collars and activity sensors $(\mathrm{n}=84) ; 46$ of these were equipped with conductivity switches to record aquatic behaviour. Offshore bears travelled longer distances at a higher speed on land and at sea away from land and had a higher activity rate compared to coastal bears. This translated into higher overall energy expenditure. Offshore bears also undertook more distant and energetically costly trips from land to the MIZ, swimming in open water. Both ecotypes showed similar seasonal patterns of activity and movement consistent with their life history linked to sea ice phenology. Despite higher energy expenditure, the offshore strategy seemed to be as profitable as the coastal one as females had marginally better spring body condition, likely due to their specialized high caloric diet of seals throughout the year. However, both ecotypes are currently experiencing habitat changes. Future studies should aim to predict how rapidly declining sea ice in the Barents Sea may challenge polar bears energetically during the coming decades.
\end{abstract}

KEY WORDS: Ursus maritimus · Sea ice phenology · Behaviour $\cdot$ Ecotype $\cdot$ Energy

${ }^{*}$ Corresponding author: marie-anne.e.blanchet@uit.no

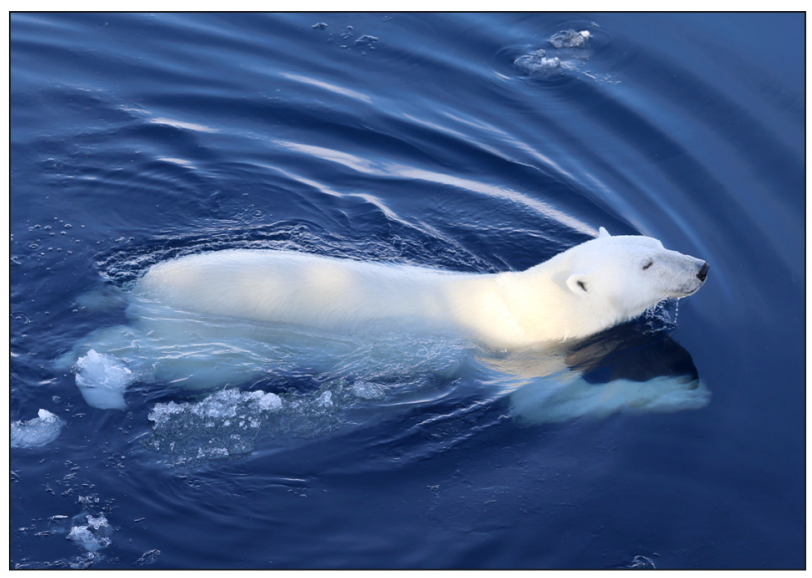

Energy requirements are higher for offshore polar bears that undertake costly swimming trips compared to coastal bears that spend most of their time on land.

Photo: Magnus Andersen, Norwegian Polar Institute

\section{INTRODUCTION}

Biological responses to environmental changes commonly fall into 3 categories according to the time scale involved: (1) short-term behavioural responses, and long-term behavioural responses leading to (2) phenological changes or (3) genetic adaptation (Hoffmann \& Sgrò 2011). While the latter occurs on a generational time-scale, the former 2 responses occur within the lifetime of individuals. Behavioural responses depend on the degree of plasticity among individuals, their dispersal abilities and the energetic cost-benefit trade-offs involved in these changes. Changes may occur in physiology or in the temporal,

() The authors 2020. Open Access under Creative Commons by Attribution Licence. Use, distribution and reproduction are unrestricted. Authors and original publication must be credited. 
spatial or phenological manifestation of behaviours. Distributional shifts (Perry et al. 2008), changes in phenology of reproduction (Bitterlin \& Van Buskirk 2014), prey switching (Abraham \& Sydeman 2006) and a combination of these factors (Reed et al. 2011) have been previously reported in a variety of species.

Polar bears Ursus maritimus, the most emblematic species of the Arctic and its top predator, are currently facing rapid environmental changes with dramatic loss of sea ice and a general warming of their environment (Derocher et al. 2004, Kovacs et al. 2011, Stern \& Laidre 2016, Descamps et al. 2017). Sea ice is their main habitat, which they use as a platform for travelling, intra-specific interactions and hunting (Amstrup 2003). Their life cycle is therefore tightly linked to the phenology of sea ice, which retreats in the spring and advances in the fall. Throughout their range, polar bears have experienced a median loss of

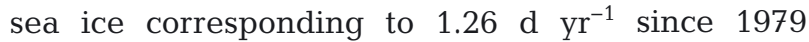
(Regehr et al. 2016), forcing behavioural changes in some populations. In some areas, these changes include spending more time on land or following summer sea ice retreat over greater distances (Stirling \& Derocher 2012, Hamilton et al. 2017, Pilfold et al. 2017, Ware et al. 2017, Lone et al. 2018). For example, the proportion of bears using coastal areas has increased in the southern Beaufort Sea and the neighbouring Chukchi Sea following sea ice reduction (Ware et al. 2017). Population-level consequences of these behavioural switches are difficult to evaluate and are likely population-dependent (Derocher et al. 2004, Stirling \& Parkinson 2006, Stirling \& Derocher 2012, Pilfold et al. 2017, Ware et al. 2017). Declines in body condition and abundance of the southern Beaufort Sea polar bear population have been related to increased use of sub-optimal coastal habitats due to sea ice loss, whereas the Chukchi Sea population is still productive under the same scenario (Rode et al. 2010, Bromaghin et al. 2015, Regehr et al. 2016, Ware et al. 2017). Some other populations have also shown signs of nutritional stress, while others seem unaffected (Rode et al. 2010, Obbard et al. 2016, Regehr et al. 2016). Although the precise underlying mechanisms in the observed differences between populations are unclear, they involve the balance between prey abundance, distribution and quality and the energetic costs of prey search, capture and handling. The population abundance of Barents Sea polar bears does not yet show signs of size reduction (Aars et al. 2009, 2017) or decreases in overall body condition (Lippold et al. 2019), although this population is currently experiencing a loss of sea ice at the highest rate in the Arctic (Stern \& Laidre 2016).
Barents Sea polar bears have been identified to exhibit 2 distinct and divergent space-use strategies: coastal and offshore (Mauritzen et al. 2001, Aars et al. 2017). Bears belonging to the former group remain within the Archipelago of Svalbard coastal area year-round, whereas the latter undertake seasonal movements between coastal areas and the retreating marginal ice zone (MIZ). Coastal bears primarily use glacier fronts and coastal areas as foraging grounds, while offshore bears switch between coastal foraging and hunting at the MIZ for seals (Freitas et al. 2012, Hamilton et al. 2017). The MIZ is defined as a transition zone between sea ice and the open ocean. It is a highly variable and productive environment subject to extreme oscillations in ice cover, fresh water inflow and surface salinity (Falk-Petersen et al. 1998). In the Svalbard region, individual space-use strategies have been stable through years, and the number of coastal bears (close to 300) did not change significantly from autumn 2004 to autumn 2015 (Aars et al. 2017, Tartu et al. 2018) despite the profound changes in sea ice availability in much of the region that occurred in 2007 (Hamilton et al. 2015, 2016). This suggests that these strategies correspond to 2 stable ecotypes and is supported by DNA sampling and mark-recapture analysis (Aars et al. 2017). Family trees comprising several generations also show that bears of the coastal ecotype settle close to where they were born (Zeyl et al. 2009). In addition, satellite telemetry and mark-recapture data show high spatial fidelity to local areas for this ecotype (Lone et al. 2013, J. Aars unpubl. data).

Polar bears with different spatial strategies have different energy requirements (Mauritzen et al. 2001, Pagano \& Williams 2019, Blévin et al. 2020). Studies on the Southern Beaufort Sea and Chukchi Sea populations suggest that energy requirements are tightly related to movement patterns (Ware et al. 2017, Pagano et al. 2018), and it has been recently shown that spatial strategy influences energy requirements for polar bears of the Barents Sea population (Blévin et al. 2020). Higher energy requirements have been related to higher energy intake and higher pollutant exposure, thus explaining higher pollutant concentrations in offshore compared to coastal bears (Olsen et al. 2003, Tartu et al. 2018, Blévin et al. 2020). Bears belonging to both ecotypes are currently experiencing different challenges. Coastal bears have already faced a rapid reduction of accessible glacier fronts and glacial ice (Hamilton et al. 2017) and a loss of their hunting platform, whereas offshore bears must track the retreating MIZ over increasing distances (Lone et al. 2018). Energy requirement for both eco- 
types of Barents Sea polar bears are likely to change dramatically in the future with the rapidly changing environment, including changes in overlap with their main prey (Hamilton et al. 2017). Thus, understanding current patterns and links between activity and energy requirements will help predict consequences of these environmental changes on both ecotypes.

The main objective of the present study was to assess differences in activity duration, energy requirements and space-use between bears belonging to both ecotypes. Specifically, we explored whether (1) activity duration was linked to movement characteristics and environmental parameters, (2) the estimated field metabolic rate (FMR) differed between ecotypes and was dependent on their behaviour and (3) the seasonality of movement affected activity duration.

\section{MATERIALS AND METHODS}

\subsection{Capture}

A total of 84 adult female polar bears (estimated ages: 5-26 yr) from the Barents Sea population were captured in the high Arctic Archipelago of Svalbard between 7 April 2011 and 22 April 2018 (see Fig. 1). No bears were instrumented in 2013. Most of the captures took place in April $(\mathrm{n}=105)$ but some collars were also fitted in March ( $\mathrm{n}=3)$, August $(\mathrm{n}=3)$ and September $(\mathrm{n}=5)$ (Table $\mathrm{S} 1$ in the Supplement at www.int-res.com/articles/suppl/m639p001_supp.pdf). Capture of polar bears followed standard protocols (Stirling et al. 1989). Adult females that appeared healthy were equipped with GPS satellite transmitters (types TGW-4678-3 and TGW-4678-4, Telonics; www. telonics.com). Morphometric measurements and the presence and age of cubs were recorded. A reproductive status was assigned to each bear as a 3 level factor: with no cub, with cub(s) of the year, or with yearling(s). Females captured in April accompanied by 2 yr olds were classified as being alone because mothers and cubs separate around that time. A body condition index (BCI) was determined according to Cattet et al. (2002). BCI is calculated based on the measured total body mass (TBM) and straight-line body length (SLBL) following the equation:

$$
\begin{aligned}
\mathrm{BCI}= & (\ln (\mathrm{TBM})-3.07 \times \ln (\mathrm{SLBL})+10.76) \div \\
& (0.17+0.009 \times \ln (\mathrm{SLBL}))
\end{aligned}
$$

We acknowledge that the BCI measured in the spring does not represent the annual body condition of the bears and that it may fluctuate differently in the 2 ecotypes throughout the year. However, spring is the only period for which we have data and where the condition of both ecotypes can be compared. All animal handling and protocols were approved by the Norwegian Animal Research Authority. The work was carried out in accordance with the relevant guidelines and regulations under permits issued by the Governor of Svalbard.

\subsection{Data collection and processing}

All numerical and statistical analyses were performed using the software R (R Core Team 2019). Location estimates were obtained by GPS and transmitted several times a day when possible via the ARGOS (Collecte Localisation Satellites) or IRIDIUM (Iridium Satellite Communications) systems. GPS locations were processed using a Kalman filter under a state-space model framework using the R package 'crawl' (Johnson et al. 2008). Processing the raw location estimates in such a way resulted in a model of the most likely path taken by each individual. The 'crawl' model accounts for variable sampling intervals, and we assigned GPS location data an accuracy of $30 \mathrm{~m}$ (Frair et al. 2010). Due to physical constraints when the bears are swimming or denning, the transmission scheme can be irregular and result in gaps in the data stream. However, this problem was minimal in our data, as $90 \%$ of the time the difference between 2 successive GPS locations was $\leq 4 \mathrm{~h}$. In addition, the structure of the missing data was similar between the data sets of bears deemed offshore and coastal (see Appendix 1 for details on the structure of the missing data). Modelled locations were predicted at the time stamps of each sensor and every $2 \mathrm{~h}$ to fill in the gaps left by missing data. In addition to positional data, activity and temperature were recorded. Activity duration was measured by an accelerometer recording the number of seconds an animal was in movement (but not necessarily in displacement) per period of time (6 h in 2011 and 2012; 2 h from 2013 onwards). For a subset of 46 individuals, the time spent in water was recorded as the percentage of time per hour the collar was wet as detected by a conductivity switch. At least one measure of resistance lower than a threshold equivalent to $1 / 4$ the normal salinity of sea water in $1 \mathrm{~s}$ was required for it to be considered a wet second (see Lone et al. 2018 for details). This information was only available for bears instrumented from 2015 through 2018 (n = 46 ind. and $\mathrm{n}=55$ collars). Data for bears instrumented in 2018 were downloaded until 31 October 2018 and are 
therefore artificially truncated. We used the abovementioned movement model to ascribe a geographical location to each sensor recording based on their time stamp. To avoid introducing bias due to differences in denning behaviour between ecotypes, denning periods were excluded from all analyses. Denning periods were identified with a custom-written function using a segmentation algorithm on smoothed speed and activity records. Possible denning periods were from 1 October through 1 May. A denning period was defined as a period of low activity and speed (due to the minimal spread of GPS positions when the animal was in the den). The segmentation algorithm finds the optimal segmentation using a dynamic programming approach. This method identifies segments from a time series that are significantly different from one another. The number of segments was then chosen using the procedure of Lavielle (2005) based on locating rupture in the penalized likelihood. We then visually inspected the identified segments to ensure that they indeed corresponded to a denning period. Segmentation was implemented using the R package 'segclust2d' (Patin et al. 2019).

Three data sets were created to regularize the tracks and match all the sensors on a common temporal scale either monthly, daily or bi-hourly. The daily data set was created by averaging daily recordings of locations and sensors. The bi-hourly data set was created only for a subset of the collars equipped with a conductivity switch from 2015-2018. To match the $2 \mathrm{~h}$ resolution of the activity data, the hourly average of the time spent in water was taken for each $2 \mathrm{~h}$ period. The location corresponding to this period was set at the beginning of the $2 \mathrm{~h}$ period and estimated based on the movement model. Activity, temperature and percentage of time spent in water were matched based on their time stamp. Finally, the monthly data set was created based on monthly averages of movement characteristics and sensor data. Months with at least $5 \mathrm{~d}$ of data were used in order to retain a high amount of data and match the cutoff used by Lone et al. (2018). Bias introduced due to a low number of days (and positions) was minimal, as $90 \%$ of the months contained at least $21 \mathrm{~d}$ of data.

\subsection{Environmental data}

Sea ice concentration. Daily estimates of sea ice concentration (12.5 km resolution) were obtained from the ARTSIST Sea Ice (ASI) algorithm based on Special Sensor Microwave Imager/Sounder instru- mentation data (SSMI/S). The ASI-SSMI/S sea ice concentration data were originally computed at the Institut Français de Recherche pour l'Exploitation de la MER (IFREMER; http://wwz.ifremer.fr), but were further processed and provided as a $5 \mathrm{~d}$ medianfiltered and gap-filled product by the Integrated Climate Data Center (ICDC). The sea ice data was downloaded from https://icdc.cen.uni-hamburg.de/1/ daten/cryosphere/seaiceconcentration-asi-ssmi.html (accessed 10 November 2018) (Kaleschke et al. 2001, Spreen et al. 2008). Daily sea ice data was obtained at each geographical location by using nearest neighbour interpolation or averaged for a specific time period (e.g. monthly). Sea ice was considered to be uniform if the concentration was $>80 \%$ and to be open water when the sea ice concentration was $<20 \%$. The Svalbard coastline, with updated positioning of glacier fronts, was obtained from the Norwegian Polar Institute (http://data.npolar.no).

Sea ice drift. Daily gridded sea ice drift data for the entire Arctic Ocean from 2011-2018 were obtained from the National Snow and Ice Data Center (NSIDC) (Tschudi et al. 2019, version 4) in order to take into account the effect of sea ice drift on the bears' movements. This data set consisted of movement on $u$ and $v$ axes at $0.1 \mathrm{~cm} \mathrm{~s}^{-1}$ in an EASE-grid projection (Lambert azimuthal equal area) with a resolution of $25 \times 25 \mathrm{~km}$.

\subsection{Movement characteristics and space use strategy}

Yearly home ranges (HRs) were defined using the minimum convex polygon (MCP) method (Mohr 1947). This method consists of calculation of the smallest convex polygon enclosing all the locations of an animal. The MCP method is easy to understand and simple to implement, completely non-parametric and does not imply any assumptions. However, it is sensitive to outliers and missing data. We chose the MCP method because we had few missing data (see Appendix 1). In addition, we considered the smallest polygon enclosing $50 \%$ of an individual's locations in order to focus on the core area occupied by each bear and to avoid taking into account unusually large excursions away from the centroid of the polygon. We then estimated the corresponding area in $\mathrm{km}^{2}$. Only yearly HRs corresponding to at least $90 \%$ of the year (10.8 mo; 329 consecutive days) were taken into account ( $\mathrm{n}=48$ collars). If a bear was tracked for several complete years, several yearly HRs were calculated for this individual and used in the ecotype com- 
parisons. For example, a bear tracked for 3 complete years contributed 3 values. Each bear and each HR were then assigned to an ecotype. This was based on the spatial overlap between yearly HRs and the Svalbard polygon defined as a polygon including the main islands of the archipelago and a $20 \mathrm{~km}$ buffer around each island (see Fig. 1). A bear was assumed to be coastal, if $>50 \%$ of its yearly HR was included within the Archipelago of Svalbard polygon, and offshore, otherwise. Attribution to either ecotype was thereafter verified visually by using each individual's tracking data. For bears that were tracked for $<90 \%$ of the year, we visually inspected the tracks and matched the individual's identification against the long-term mark-recapture database from the Norwegian Polar Institute. As the offshore bears use other areas away from Svalbard most of the time, the likelihood of recapture is very low. Coastal bears, on the other hand, are captured between 4 and 7 times during their adult life. If a bear had been captured several times, this individual was assigned to the coastal ecotype, otherwise it was assigned to the offshore ecotype.

Several movement variables were calculated. Daily average speed corrected for sea ice drift was calculated following the approach taken by Auger-Méthé et al. (2016) and Durner et al. (2017). Each daily location was paired spatially and temporally with a daily ice drift estimate. The true movement vector of the bear was calculated by subtracting the ice drift vector from the collar displacement vector. Speed was then calculated as the distance (great-circle distance) travelled between 2 successive daily locations divided by $24 \mathrm{~h}$. All speeds presented and analysed hereafter are sea ice drift-corrected. Maximum distance between the capture location $(\mathrm{km})$ and the last location of the track was also calculated using the great-circle distance. The proportion of time spent on land was calculated as the ratio of the number of days on land out of the total track duration for each ecotype.

Monthly HR sizes per day (monthly HR divided by the number of days in a month) were also calculated. We used this metric in order to retain the maximum amount of data and allow comparisons between months. This metric was relatively unbiased because $90 \%$ of the months contained at least $21 \mathrm{~d}$ of data with an average of $28.3 \mathrm{~d} \mathrm{mo}^{-1}$. If a bear was instrumented for more than $1 \mathrm{yr}$, several monthly HRs were calculated for the same month. Hence, polar bears instrumented for multiple years contributed to multiple monthly values. Calculations were made with the 'adehabitatHR' package (Calenge 2006).

\subsection{FMR estimates}

We estimated FMR for each bear based on their estimated average daily speed corrected for sea ice drift. Speed reflects polar bear FMR better than activity. Therefore, we estimated FMR for each bear based on their average daily drift-corrected speed following the relationship in Pagano et al. (2018):

$$
\text { Daily FMR = } 167.3 \times \text { speed }+153
$$

where daily FMR is in $\mathrm{kJ} \mathrm{kg}^{-1} \mathrm{~d}^{-1}$, speed is in $\mathrm{km} \mathrm{h}^{-1}$, 153 represents the $y$-intercept (metabolic rate without locomotion) in $\mathrm{kJ} \mathrm{kg}^{-1} \mathrm{~d}^{-1}$ and 167.3 represents the slope in $\mathrm{kJ} \mathrm{kg}^{-1}$ per unit of speed in $\mathrm{km} \mathrm{h}^{-1}$. For bears carrying instruments with a conductivity switch, we corrected this FMR by the percentage of time spent in the water each day:

Daily $\mathrm{FMR}_{\mathrm{corr}}=$

$\mathrm{FMR}_{\text {walking }} \times \%$ walking $+\mathrm{FMR}_{\text {swimming }} \times \%$ swimming

where $\mathrm{FMR}_{\text {walking }}=$ daily FMR estimated from Pagano et al. (2018) and FMR swimming $=2.75 \mathrm{ml} \mathrm{O}^{2} \mathrm{~g}^{-1} \mathrm{~h}^{-1}$ based on Griffen (2018). We converted the latter using the standard conversion factor of $20.083 \mathrm{~J} \mathrm{ml}^{-1}$ $\mathrm{O}_{2}$ (Schmidt-Nielsen 1997). $\mathrm{FMR}_{\text {swimming }}=1325 \mathrm{~kJ}$ $\mathrm{kg}^{-1} \mathrm{~d}^{-1}$.

The FMR based only on drift-corrected speed and the FMR corrected by the percentage of time spent in water were analysed separately because not all collars were equipped with conductivity switches.

\subsection{Budget time, activity and substrates}

Monthly time spent on ice and on land were based on the modelled locations at each time stamp. Monthly proportions of time spent in the water were calculated based on information obtained from collars with a conductivity switch. A bear was assumed to be in the water when the collar was wet (based on data from the conductivity switch) and not on land based on its position. We combined these 2 data sources to avoid errors linked to the uncertainty around each GPS location and in the bathymetric and land maps. Conversely, a bear was assumed to be on land when its location was assigned inside a Svalbard land polygon and when it was dry based on the information from the conductivity switch. This condition was added in order to avoid including data when the bears were along the shore but in water.

Activity recordings were partitioned by behaviour and ecotype. We specifically looked at the distribu- 
tion of activity duration for 3 different behaviours: (1) when the bears were on land and not wet (walking, hunting or resting); (2) when the bears were on sea ice of at least $80 \%$ concentration and not wet (walking, hunting or resting); and (3) when bears were wet for at least $75 \%$ (1 h $30 \mathrm{~min})$ of a $2 \mathrm{~h}$ period and not on land.

We then defined a swimming trip (hereafter 'trip') as an aquatic excursion where the bear was in water for at least $75 \%$ of 3 consecutive $2 \mathrm{~h}$ periods (i.e. at least $4.5 \mathrm{~h}$ in water) and not on land. Summary statistics for each trip were calculated including distance, duration, average hourly activity and time interval between 2 consecutive trips. The distance swam during a trip was calculated as the great-circle distance between the start and end points.

\subsection{Statistical analysis}

All numerical and statistical analysis were done using R v.3.5.2 (R Core Team 2019). All means are presented \pm SD. Effect sizes were estimated from models with $95 \%$ CIs. We included bear identity as a random effect to account for the dependency between measures of the same individual. Year of tagging to account for year differences in tracking duration was also included in the model. Reproductive status was included as an additive fixed effect in all models exploring the differences in movement metrics and the FMR between ecotypes. Out of $116 \mathrm{col}-$ lars, 35 were on coastal females with cubs of the year, 8 with yearlings and 44 lone; 2 collars belonged to offshore females with cubs of the year, 3 with yearlings and 24 lone. Due to this very unbalanced sampling between reproductive status and ecotype, and the few number of levels (3) for this factor, only an additive effect could be tested and it was not possible to include it as a random effect or as an interaction (Bolker et al. 2009). In addition, reproductive status was not included in the model exploring differences in yearly HR size across ecotypes due to low sample size of offshore bears with cubs tracked for at least $90 \%$ of the year $(n=2)$. When necessary, response variables were log-transformed or square root-transformed to achieve normality and stabilize the variance. Preliminary analysis showed that tracking duration depended on the year of tagging (likelihood ratio test, $\mathrm{LRT}=28.9 \mathrm{p}<0.0001$ ) and that bears tagged in 2016 ( $n=15$ collars) were tracked for a significantly shorter amount of time than the other years $\left(\operatorname{mean}_{2016}=134 \pm 75 \mathrm{~d} ;\right.$ mean $\left._{\text {all }}=375 \pm 233 \mathrm{~d}\right)$. Year of tagging was included as a random effect in all subse- quent models. Model selection was done based on Akaike's information criterion (AIC) and differences in $\mathrm{AIC}(\triangle \mathrm{AIC})$.

We first tested whether age, weight, tracking duration and BCI of the bears differed between ecotypes. We used linear mixed effect models (LMEs) using the 'nlme' package (Pinheiro et al. 2018) and tested the difference between each best-fitted model and the null model using a LRT.

We then tested the effect of ecotype on movement parameters, such as yearly HR size, average daily speed, maximum distance from capture location, proportion of time spent on land, trip duration, trip total distance, interval between 2 consecutive trips and average hourly activity during a trip, using LMEs. Average daily FMR and corrected daily FMR incorporating the cost of swimming and activity were also tested in the same way between the 2 ecotypes.

Generalized additive mixed models (GAMMs) were chosen to model the non-linear influence of several covariates. The error structure included bear identity and year of tagging as random effects and an autoregressive correlation term with a lag of 1 (corAr1) to remove autocorrelation in the residuals. Residuals were assumed to follow a Gaussian distribution. We tested whether daily speed influenced daily activity readings on land and on sea ice with concentration $>80 \%$. Further, we tested the influence of sea ice concentration on activity durations, with sea ice concentration as a smooth predictor term. Finally, we explored possible differences in seasonal trends in activity, daily HR size and speed using GAMMs, with month as a smooth term. To investigate whether the above-mentioned relationships differed between coastal and offshore bears, an interaction between month and ecotype was considered. The models were fitted with the 'mgcv' package (Wood 2003). Differences linked to the ecotypes were further tested within each month using LME and LRT.

\section{RESULTS}

We obtained 116 polar bear tracks representing 84 individuals among which 19 were captured more than once (up to 5 times). In addition, 32 individuals were tracked for more than 1 yr (up to $3 \mathrm{yr}$ ) with the same collar. We classified 28 individuals as offshore $(\mathrm{n}=29$ collars) and 56 individuals as coastal ( $\mathrm{n}=87$ collars) (Fig. 1). One of the offshore females was instrumented twice and 8 of them were tracked for more than $1 \mathrm{yr}$ (Table S1). The total tracking duration ranged from 25-1193 d with an average of $338 \pm 233$ d excluding 


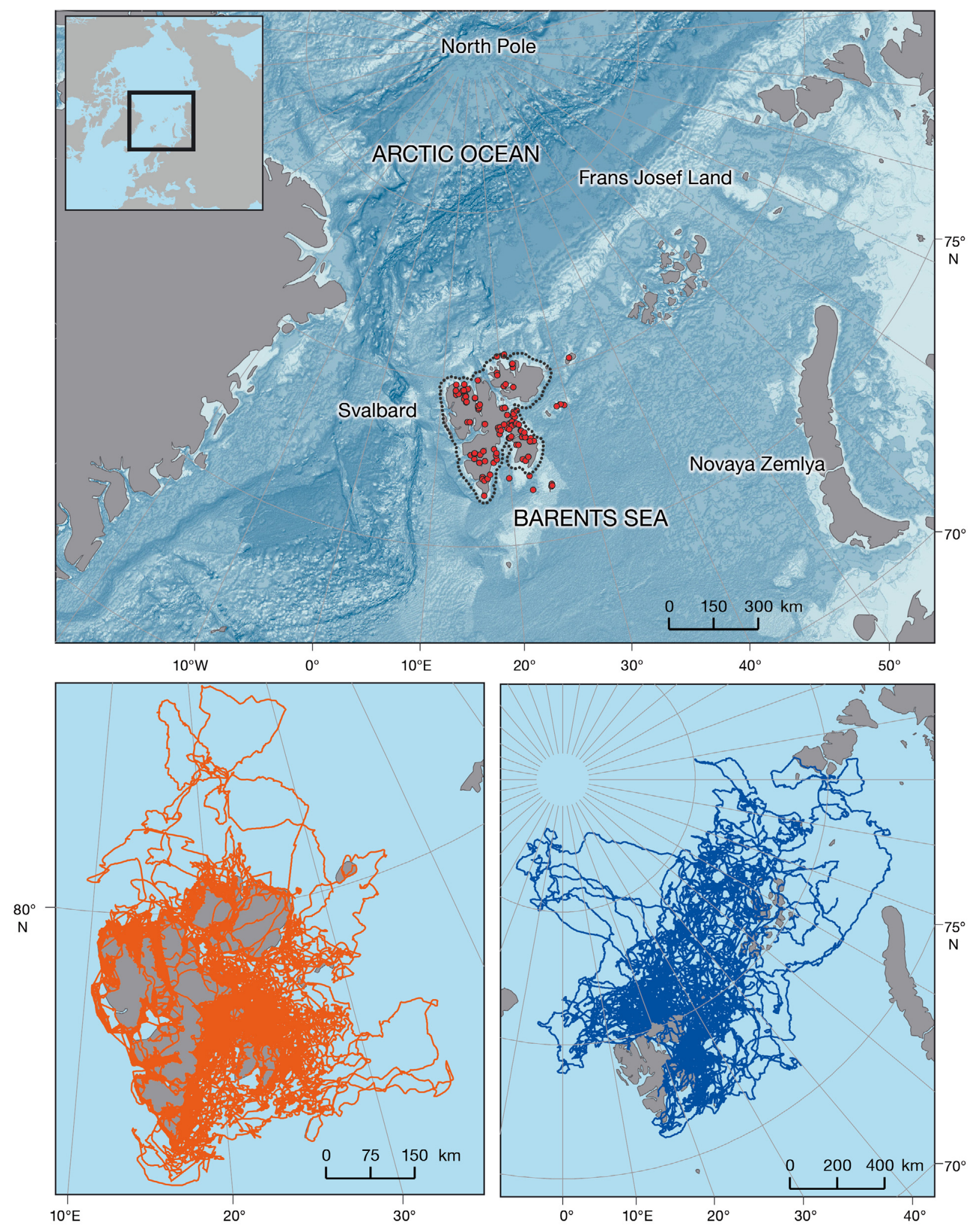

Fig. 1. Top map: study area within the larger Barents Sea area. Red dots: capture locations of 84 female polar bears equipped with satellite transmitters between 2011 and 2018; black line: extent of the Svalbard defined as a polygon including the main islands of the archipelago and a $20 \mathrm{~km}$ buffer around each island. Inset: study area represented by a black square within a wider spatial context. Bottom maps: GPS tracks of coastal bears (orange) and offshore bears (blue) 
Table 1. Summary statistics of biological data and average daily movement characteristics for polar bears belonging to each ecotype (coastal, offshore). Likelihood ratio tests (LRT) and associated p-values show the difference between models including ecotype as an explanatory variable and the null model

\begin{tabular}{|c|c|c|c|c|c|c|c|c|}
\hline \multirow[t]{2}{*}{ Response variable } & \multicolumn{3}{|c|}{$\begin{array}{c}\text { Coastal } \\
\left(\mathrm{n}_{\text {collars }}=87 ; \mathrm{n}_{\text {bears }}=56\right)\end{array}$} & \multicolumn{3}{|c|}{$\begin{array}{c}\text { Offshore } \\
\left(\mathrm{n}_{\text {collars }}=29 ; \mathrm{n}_{\text {bears }}=28\right)\end{array}$} & \multirow[t]{2}{*}{ LRT } & \multirow[t]{2}{*}{$\mathrm{p}$} \\
\hline & Mean & & Range & & & Range & & \\
\hline Tracking duration (d) & 329 & 351 & $25-733$ & 364 & 210 & $37-1193$ & 0.17 & 0.68 \\
\hline Age $(y r)$ & 12.4 & 11 & $5-26$ & 11.9 & 11 & $5-25$ & 0.50 & 0.47 \\
\hline Body Condition Index & -1.53 & -1.47 & -3.10 to -0.22 & -1.13 & -1.00 & -3.25 to -0.17 & 6.40 & 0.01 \\
\hline Yearly home-range size $\left(\mathrm{km}^{2}\right)$ & 3207 & 1451 & 68-14868 & 90678 & 49992 & $743-397274$ & 17.90 & $<0.001$ \\
\hline Maximum distance from capture location $(\mathrm{km})$ & 135 & 112 & $19-560$ & 667 & 550 & $175-1623$ & 74.03 & $<0.0001$ \\
\hline Average daily speed $\left(\mathrm{km} \mathrm{h}^{-1}\right)$ & 0.27 & 0.16 & $0-3$ & 0.56 & 0.46 & $0-3.4$ & 48.20 & $<0.001$ \\
\hline Percentage of time spent on land (\%) & 49 & 49 & 5-95 & 8 & 3 & $0-35$ & 89.01 & $<0.0001$ \\
\hline Average daily activity $\left(\mathrm{s} \mathrm{h}^{-1}\right)$ & 583 & 597 & $232-881$ & 763 & 756 & $371-1170$ & 31.00 & $<0.0001$ \\
\hline \multirow[t]{2}{*}{ Average daily FMR $\left(\mathrm{kJ} \mathrm{kg}^{-1}\right)$} & 201 & 199 & $164-246$ & 263 & 257 & $194-372$ & 86.00 & $<0.0001$ \\
\hline & \multicolumn{3}{|c|}{$\left(\mathrm{n}_{\text {collars }}=45, \mathrm{n}_{\text {bears }}=36\right)$} & \multicolumn{3}{|c|}{$\left(\mathrm{n}_{\text {collars }}=10 ; \mathrm{n}_{\text {bears }}=10\right)$} & & \\
\hline Average corrected daily FMR $\left(\mathrm{kJ} \mathrm{kg}^{-1} \mathrm{~d}^{-1}\right)$ & 265 & 261 & $164-396$ & 340 & 346 & $241-439$ & 13.00 & $<0.0001$ \\
\hline Trip duration (h) & 9.3 & 8 & $6-28$ & 15.1 & 10 & $6-88$ & 11.64 & $<0.0001$ \\
\hline Distance $(\mathrm{km})$ & 7.7 & 5 & $0.04-47$ & 27.4 & 19.6 & $2.3-176$ & 18.37 & $<0.0001$ \\
\hline Time interval between 2 trips (d) & 17 & 5.6 & $0.25-347$ & 36 & 15.3 & $0.4-262$ & 3.10 & 0.08 \\
\hline Hourly activity trip ${ }^{-1}$ (min) & 8 & 7 & $1-20$ & 14 & 14 & $4-29$ & 14.67 & $<0.0001$ \\
\hline
\end{tabular}

2018 (Tables 1 \& S1). The tracking duration and age of the bears were independent of the ecotype, as models with ecotype as an explanatory variable were not significantly different from the null models (Table 1). Offshore bears were in slightly better condition in the spring compared to coastal bears as shown by higher values of BCI (Table 1). Differences in estimated BCI translated into an average weight difference of 13.4 $\mathrm{kg}(95 \% \mathrm{CI}=3.1-23.1 \mathrm{~kg})$ for bears with an average length. This effect of ecotype was, however, marginal when considering a subsample of only lone females with $\mathrm{n}_{\text {offshore }}=24$ and $\mathrm{n}_{\text {coastal }}=44(\mathrm{LRT}=3.7, \mathrm{p}=0.06)$. The difference of $9.0 \mathrm{~kg}(95 \% \mathrm{CI}=-0.3-20.0 \mathrm{~kg})$ between coastal and offshore bears was likely enhanced by females with cubs of the year in the coastal ecotype sample.

\subsection{Movement characteristics}

The yearly HR size for coastal polar bears ranged from $68-14868 \mathrm{~km}^{2}$. It was on average 17 times larger for offshore bears (95\% CI $=5-58)$, ranging from 744-397 $274 \mathrm{~km}^{2}$ (Tables 1 \& S2). Average daily speed of offshore bears was 1.6 times greater (95\% $\mathrm{CI}=1.4-1.7)$ than for coastal bears (Tables $1 \& \mathrm{~S} 2$ ). The average maximum distance from the tagging location was 4.8 times greater $(95 \% \mathrm{CI}=2.7-6.6)$ for offshore bears compared to coastal bears. The females also allocated their time on land differently accord- ing to their ecotype. Coastal bears spent on average $72 \%$ of their time on land $(95 \% \mathrm{CI}=67-76 \%)$, compared to on average $18 \%(95 \% \mathrm{CI}=5-31 \%)$ for offshore bears (Tables $1 \&$ S2).

\subsection{Activity, substrate and FMR}

The percentage of transmitted activity data per collar was almost complete with an average of $96.0 \pm$ $0.1 \%$, and therefore there was no diel or seasonal bias in the activity data. Average daily activity duration per hour was $31 \%$ greater $(95 \% \mathrm{CI}=22-39 \%)$ for offshore bears compared to coastal ones (Fig. 2a, Tables 1 \& S2).

Average daily activity duration for both ecotypes increased with speed, being on land and being on sea ice concentrations greater than $80 \%$ (Table 2, Fig. 2b,c). Average daily activity duration increased almost linearly as a function of the sea ice concentration for both ecotypes in a similar way, although this increase was small from a median of 12 min activity $\mathrm{h}^{-1}$ when the bears were on sea ice concentrations $<20 \%$ to $14 \mathrm{~min}$ activity $\mathrm{h}^{-1}$ when the bears were on sea ice concentrations $>80 \%$ (Fig. 2d). Average daily FMR was $32 \%$ higher $(95 \% \mathrm{CI}=26-37 \%)$ for offshore bears compared to coastal ones (Fig. 3, Tables $1 \&$ S2) and this difference was similar $(29 \%)$ when corrected for proportion of time in water, although the $95 \%$ CI was wider (95\% CI = 313-49\%) (Fig. 3, Tables 1 \& S2). 

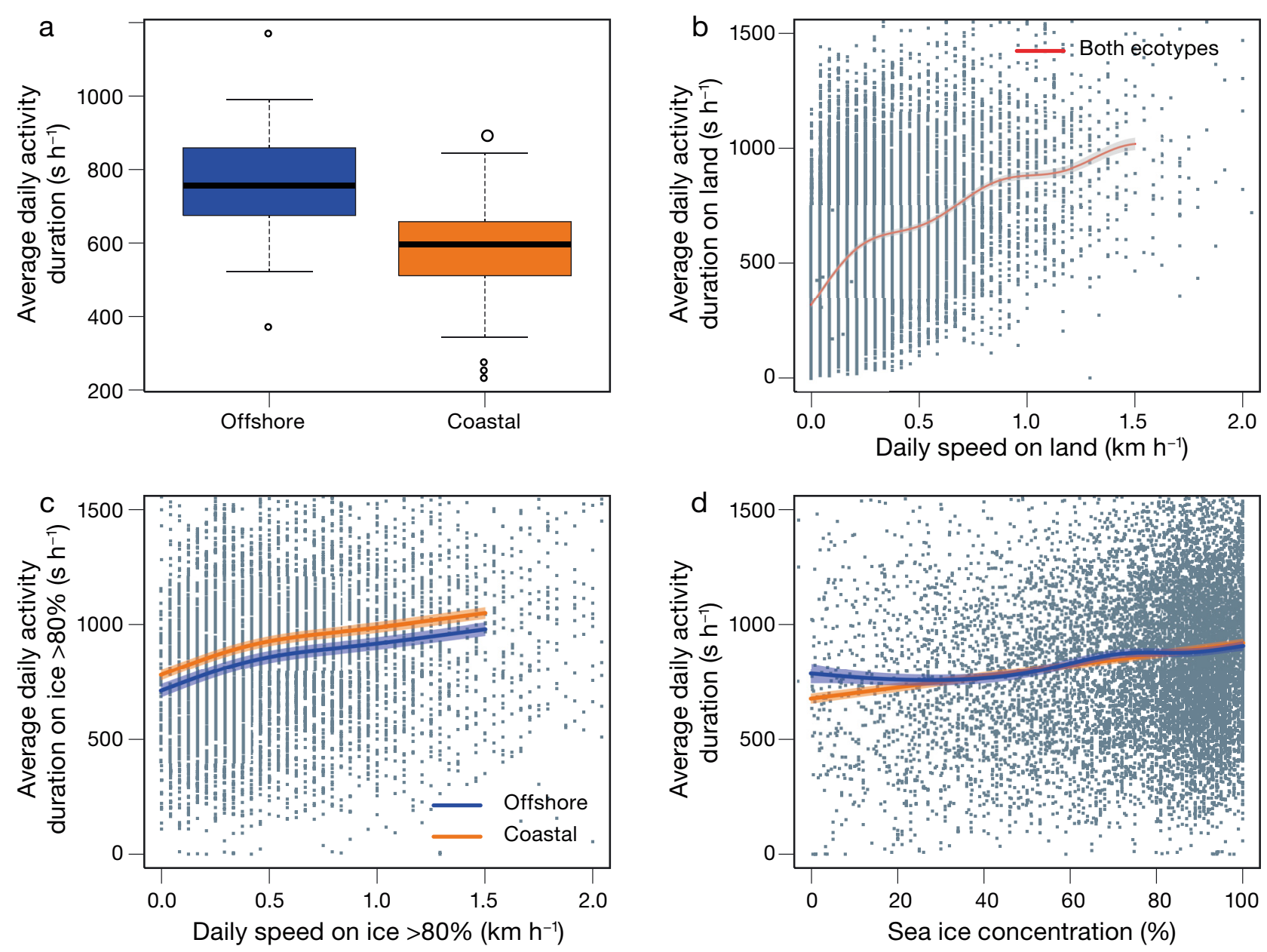

Fig. 2. (a) Average daily activity duration for 28 offshore and 56 coastal polar bears instrumented on the Svalbard Archipelago during 2011-2018. Box plots show median values with interquartile ranges (boxes), whiskers indicate the range of data, outliers are given as open circles. Average daily activity duration is also given as a function of (b) average daily speed when the bears were on land, (c) average daily ice drift-corrected speed when the bears were on ice of concentration $>80 \%$ and (d) sea ice concentration. Grey dots: raw data; coloured curves: predicted curves based on generalised additive mixed models; shaded areas: modelled $95 \%$ CIs. The predicted curve in red represents the population average for both ecotypes as this term did not improve the fit of the model

\subsection{Seasonal variation in space use}

Monthly HR size, speed and activity varied throughout the year in a similar fashion for both ecotypes, but offshore bears generally showed greater values compared to coastal ones (Figs. 4 \& S1, Table 2). However, the differences in HR size, speed and activity between the ecotypes were not consistent for all months (Fig. 4, Table 3). During winter, offshore bears had greater HR sizes, higher speeds and were more active than coastal bears. There was a strong seasonality in activity pattern regardless of ecotype. Bears were generally the most active toward the end of the winter with a peak in May-June (Figs. 4c \& S1). The lowest activity levels occurred during the late summer in August-September.

\subsection{Time budgets on various substrates and seasonality}

A total of 55 collars corresponding to 46 bears carried instruments with a conductivity switch that transmitted the percentage of time spent in water in a $2 \mathrm{~h}$ period. The percentage of transmitted time-inwater data was almost complete with an average of $99.0 \pm 1.0 \%$ of the recorded data transmitted, and therefore there was no diel or seasonal bias in the percentage of time-in-water data due to incomplete transmission. Average monthly proportion of time spent on different substrates showed a strong seasonality that was similar for both ecotypes (Fig. 5). Time spent in water ranged between 0 and $26 \%$ with a monthly average of $5 \%$ and was higher between 
Table 2. Generalized additive models explaining activity and movement parameters for 84 female polar bears instrumented in the Barents Sea (2011-2018). Explanatory variables considered were speed, sea ice concentration, month and ecotype (coastal, offshore); s: smooth term; HR: home range. Difference in Akaike's information criterion ( $\triangle \mathrm{AIC}$ ) between models is presented. The best fitted models are in bold

\begin{tabular}{|c|c|c|}
\hline Response variable & Model structure & $\Delta \mathrm{AIC}$ \\
\hline $\begin{array}{l}\text { Average daily activity } \\
\text { duration on land }\end{array}$ & $\begin{array}{l}\text { Act } \sim \text { s(speed) } \\
\text { Act } \sim \text { s(speed) + ecotype } \\
\text { Act } \sim \text { s(speed, by=ecotype) } \\
\text { Act } \sim 1\end{array}$ & $\begin{array}{r}0 \\
1.2 \\
21.2 \\
6241.2\end{array}$ \\
\hline $\begin{array}{l}\text { Average daily activity } \\
\text { duration on solid sea ice }\end{array}$ & $\begin{array}{l}\text { Act } \sim \text { s(speed)+ecotype } \\
\text { Act } \sim \text { s(speed) } \\
\text { Act } \sim \text { s(speed,by=group) } \\
\text { Act } \sim 1\end{array}$ & $\begin{array}{r}0 \\
1.86 \\
10.85 \\
353.48\end{array}$ \\
\hline $\begin{array}{l}\text { Average daily activity } \\
\text { duration at sea }\end{array}$ & $\begin{array}{l}\text { Act } \sim \text { s(seaice, by=ecotype) } \\
\text { Act } \sim \text { s(seaice) } \\
\text { Act } \sim \text { s(seaice) + ecotype } \\
\text { Act } \sim 1\end{array}$ & $\begin{array}{c}0 \\
1.1 \\
3.1 \\
215\end{array}$ \\
\hline Monthly HR size $\mathrm{d}^{-1}$ & $\begin{array}{l}\text { HR s(month)+ecotype } \\
\text { HR s(month) } \\
\text { HR s(month, by=ecotype) } \\
\text { HR ecotype } \\
\text { HR 1 }\end{array}$ & $\begin{array}{r}0 \\
67.125 \\
79.854 \\
126.844 \\
198.698\end{array}$ \\
\hline Monthly speed & $\begin{array}{l}\text { Speed } \sim \text { s(month)+ecotype } \\
\text { Speed s(month) } \\
\text { Speed s(month,by=ecotype) } \\
\text { Speed ecotype } \\
\text { Speed 1 }\end{array}$ & $\begin{array}{c}0 \\
24.472 \\
35.514 \\
120.37 \\
147.271\end{array}$ \\
\hline Monthly activity & $\begin{array}{l}\text { Activity } \sim \text { s(month)+ecotype } \\
\text { Activity } \sim \text { s(month) } \\
\text { Activity } \sim \text { s(month,by=ecotype) } \\
\text { Activity } \sim \text { ecotype } \\
\text { Activity } \sim 1\end{array}$ & $\begin{array}{r}0 \\
18.56 \\
28.14 \\
580.24 \\
603.88\end{array}$ \\
\hline
\end{tabular}

June and August compared to the rest of the year (Fig. 5a). There was no significant difference in the time spent in water between ecotypes, except in May when offshore bears spent more time in water compared to coastal ones $\left(\right.$ mean $_{\text {offshore }}=5.0 \pm$ $4.1 \%$; mean $_{\text {coastal }}=2.7 \pm 2.0 \%$ ) (Table 3$)$. The proportion of time spent on land and on sea ice $>80 \%$ varied considerably with season and also showed large individual variability. Bears spent the least amount of time on land between April and June when they used sea ice (Fig. 5b,c). On average, coastal females spent more time on land and less time on sea ice than offshore bears (Fig. 5b,c). However, individual variability was high.

\subsection{Activity and aquatic behaviour}

The distributions of activity durations were similar for both ecotypes when the bears were on land or on sea ice and not swimming (Fig. 6a,b). However, the activity pattern was very different when the bears were swimming for at least $1 \mathrm{~h}$ 30 min within a $2 \mathrm{~h}$ period, which occurred at least once for 45 different individuals ( $\mathrm{n}=52$ collars). During these aquatic periods, offshore bears were twice as active compared to coastal bears $\left(\right.$ mean $_{\text {offshore }}=$
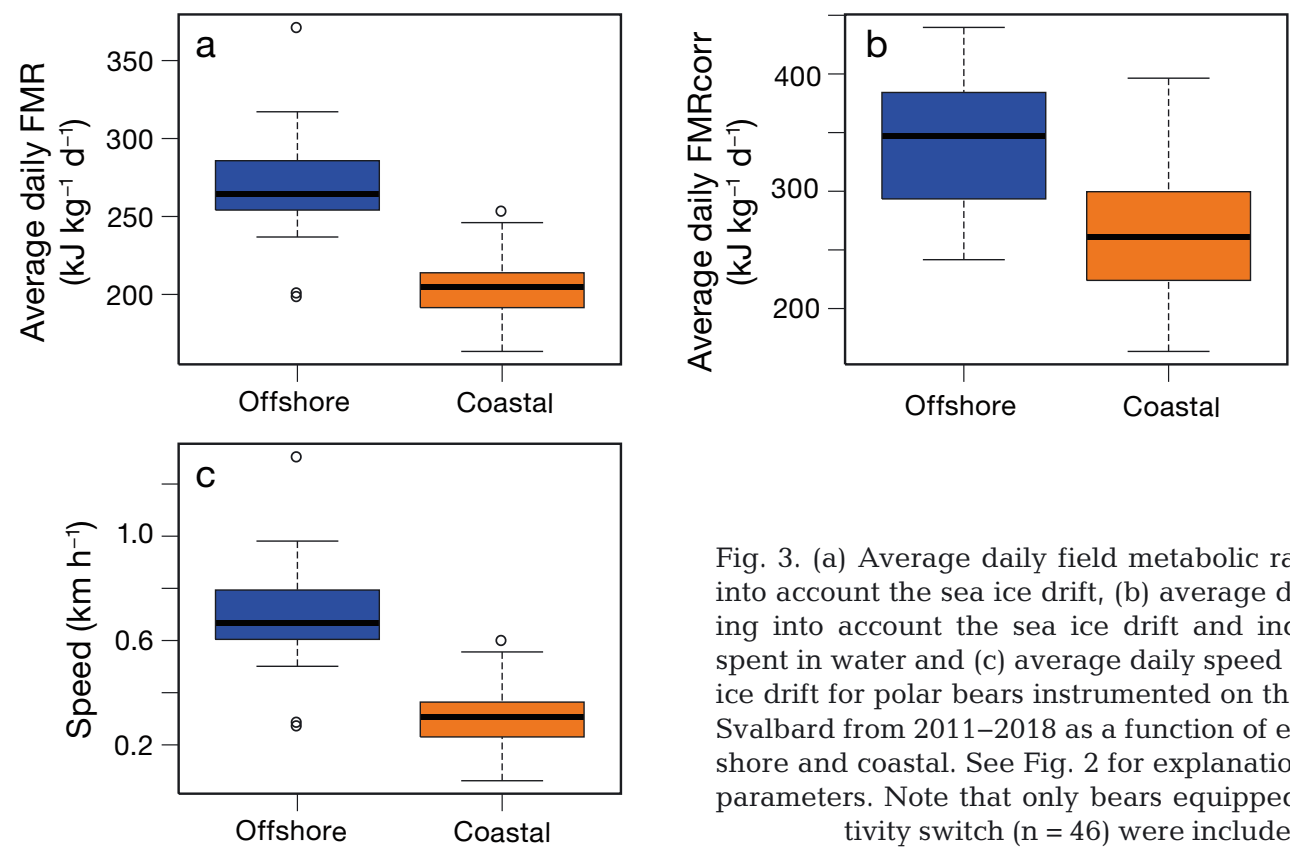

Fig. 3. (a) Average daily field metabolic rate (FMR) taking into account the sea ice drift, (b) average daily $F_{\text {MR }}$ corr taking into account the sea ice drift and including the time spent in water and (c) average daily speed corrected for sea ice drift for polar bears instrumented on the Archipelago of Svalbard from 2011-2018 as a function of each ecotype: offshore and coastal. See Fig. 2 for explanation of the box plot parameters. Note that only bears equipped with a conductivity switch $(\mathrm{n}=46)$ were included in $(\mathrm{b})$ 

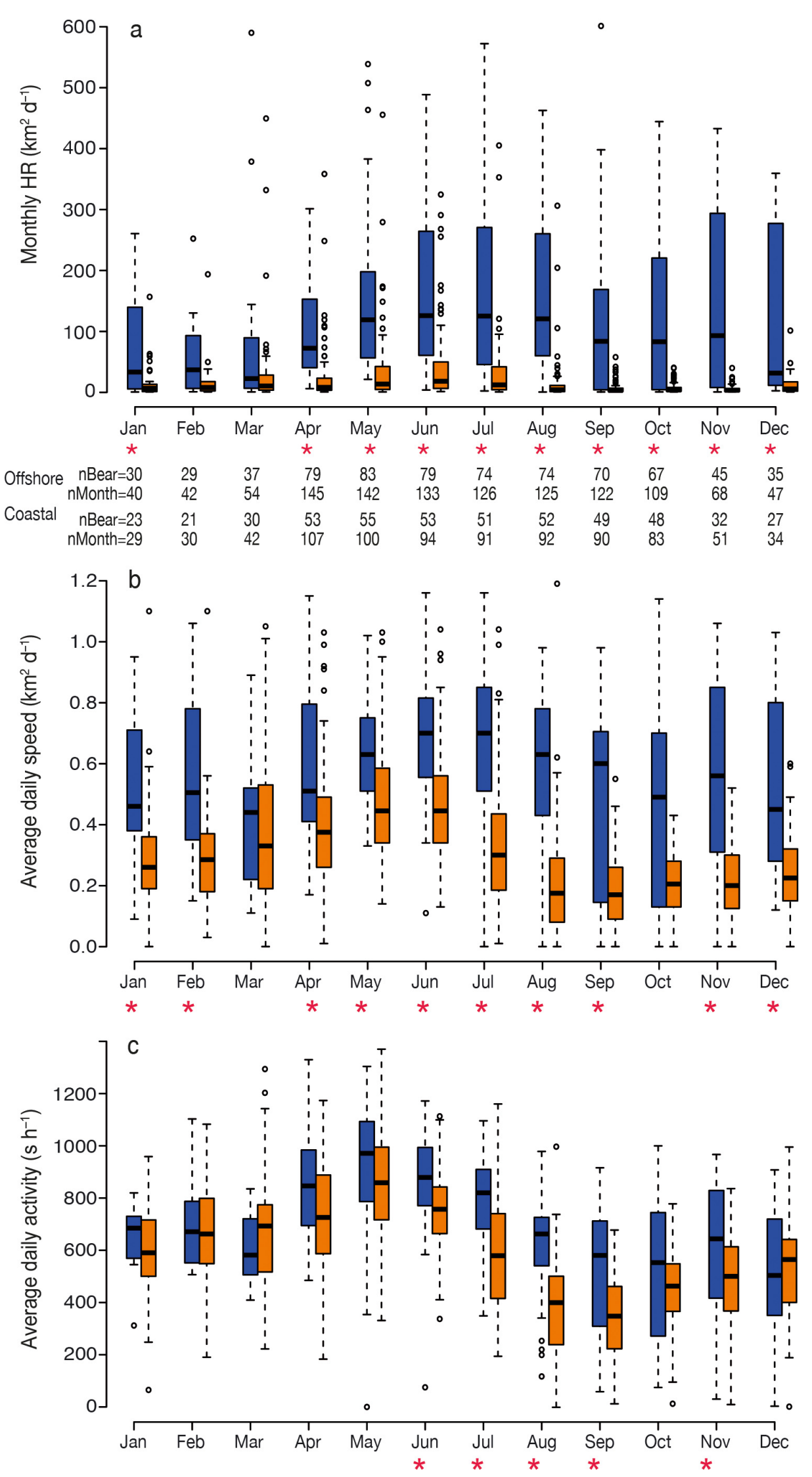

Fig. 4. (a) Monthly home range (HR) area and average (b) daily speed and (c) hourly activity per month for 84 polar bears instrumented on the Archipelago of Svalbard from 2011-2018 for each ecotype: offshore and coastal. Plotted values are monthly aggregates (given by 'nMonth') for individual polar bears (given by 'nBear'), with polar bears tagged for multiple years contributing multiple monthly values. All calculations are based on records excluding denning periods. See Fig. 2 for explanation of the box plot parameters. Red stars: months for which values for both spatial strategies were significantly different from each other 
Table 3. Likelihood ratio tests (LRT) for linear mixed effect models examining differences in polar bear home range (HR) size, speed and activity between models including the spatial strategy and the null model

\begin{tabular}{|c|c|c|}
\hline Response variable & LRT & $\mathrm{p}$ \\
\hline \multicolumn{3}{|c|}{ Monthly HR size $d^{-1}$} \\
\hline Jan & 6.83 & 0.0089 \\
\hline Feb & 3.58 & 0.0587 \\
\hline Mar & 2.80 & 0.0938 \\
\hline Apr & 13.30 & $<0.001$ \\
\hline May & 30.26 & $<0.0001$ \\
\hline Jun & 26.31 & $<0.0001$ \\
\hline Jul & 38.56 & $<0.0001$ \\
\hline Aug & 25.07 & $<0.0001$ \\
\hline Sep & 31.75 & $<0.0001$ \\
\hline Oct & 36.57 & $<0.0001$ \\
\hline Nov & 22.30 & $<0.0001$ \\
\hline Dec & 7.52 & 0.0061 \\
\hline \multicolumn{3}{|l|}{ Monthly speed } \\
\hline Jan & 8.46 & 0.0036 \\
\hline Feb & 8.00 & 0.0047 \\
\hline Mar & 1.76 & 0.18 \\
\hline Apr & 30.59 & $<0.0001$ \\
\hline May & 38.90 & $<0.0001$ \\
\hline Jun & 36.30 & $<0.0001$ \\
\hline Jul & 47.55 & $<0.0001$ \\
\hline Aug & 53.06 & $<0.0001$ \\
\hline Sep & 45.69 & $<0.0001$ \\
\hline Oct & 30.26 & $<0.0001$ \\
\hline Nov & 35.20 & $<0.0001$ \\
\hline Dec & 14.19 & 0.0002 \\
\hline \multicolumn{3}{|l|}{ Monthly activity } \\
\hline Jan & 0.51 & 0.47 \\
\hline Feb & 0.00 & 0.98 \\
\hline Mar & 0.57 & 0.44 \\
\hline Apr & 6.33 & 0.01 \\
\hline May & 2.84 & 0.09 \\
\hline Jun & 5.50 & 0.0183 \\
\hline Jul & 17.49 & $<0.0001$ \\
\hline Aug & 28.67 & $<0.0001$ \\
\hline Sep & 17.09 & $<0.0001$ \\
\hline Oct & 2.94 & 0.0859 \\
\hline Nov & 5.50 & 0.0187 \\
\hline Dec & 0.01 & 0.91 \\
\hline
\end{tabular}

$30.5 \pm 18.0 \mathrm{~min}$ per $2 \mathrm{~h}$, mean $\mathrm{n}_{\text {coastal }}=15.7 \pm 13.0 \mathrm{~min}$ per 2 h; Fig. 6c). A total of 281 trips of at least 6 h were identified; 55 belonging to offshore bears and 226 to coastal ones. The majority of trips lasted $<20 \mathrm{~h}$ for both ecotypes, but offshore bears undertook some longer swimming excursions of up to $88 \mathrm{~h}$ and swam over longer distances of up to $176 \mathrm{~km}$ (Fig. 7a,b). The average trip duration was greater for offshore bears compared to coastal ones $\left(\right.$ mean $\left._{\text {offshore }}=15.7 \pm 14.0 \mathrm{~h}\right)$,

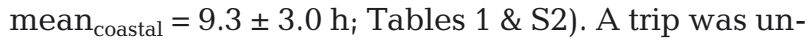
dertaken on average every $21 \pm 43 \mathrm{~d}$, and this interval did not depend on ecotype. The distribution of the sum of activity during the trip depended on ecotype with offshore bears showing greater activity readings compared to coastal ones (Fig. $7 \mathrm{~d})\left(\right.$ mean $_{\text {offshore }}=14.6$ $\pm 6.5 \mathrm{~min}$ per $2 \mathrm{~h}$, mean $_{\text {coastal }}=9.3 \pm 2.6 \mathrm{~min}$ per $2 \mathrm{~h}$ ). Trips undertaken by coastal bears were distributed mainly along the coastline or across fjords, whereas trips by offshore bears were undertaken between the coasts of Svalbard and the MIZ across open waterbodies (Fig. S2).

\section{DISCUSSION}

The present study shows that the 2 Barents Sea polar bear ecotypes differed in their habitat use and activity levels. This translates into higher energy expenditure for offshore bears and is linked partly to their aquatic behaviour. Both ecotypes, however, showed similar seasonal patterns of activity and movement consistent with their life history linked to sea ice phenology.

Space-use differed strikingly between both ecotypes with offshore polar bears occupying larger areas and covering larger distances at higher speed compared to c oastal bears (Fig. S3). This is consistent with previous studies in the same region (Mauritzen et al. 2001, 2002, Hamilton et al. 2017, Tartu et al. 2018) and other regions (Stirling \& Parkinson 2006, Pagano \& Williams 2019). There were large interindividual variations within ecotypes suggesting that individual polar bears differ in their habitat use. This might be related to individual hunting strategies. For example, one coastal bear in the present study occupied a yearly HR of $68 \mathrm{~km}^{2}$ and stayed for the major part of the year within one fjord at a glacier front presumably hunting seals (Fig. S3). On the other hand, another coastal bear had a yearly HR of nearly $15000 \mathrm{~km}^{2}$ due to a large excursion to the northern part of the Barents Sea. Similarly, offshore bears' yearly HR size varied between 700 and nearly $250000 \mathrm{~km}^{2}$. This illustrates the inter-individual behavioural variation in polar bears that occupy a dynamic habitat and must adjust to variable prey distribution and abundance. The greatest variability in movement parameters was observed in the offshore ecotype, which is likely linked to the dynamic characteristics of the sea ice and the large distances between the MIZ and their land denning sites. In addition, the patchy nature of seal distribution in the MIZ might explain the long distance movements of offshore bears when foraging (Nilssen et al. 1991, Kovacs et al. 2011, Kovacs 2018). The inter-individual variability in polar bear space use also suggests a potential for switching strategies even if these are usually sta- 

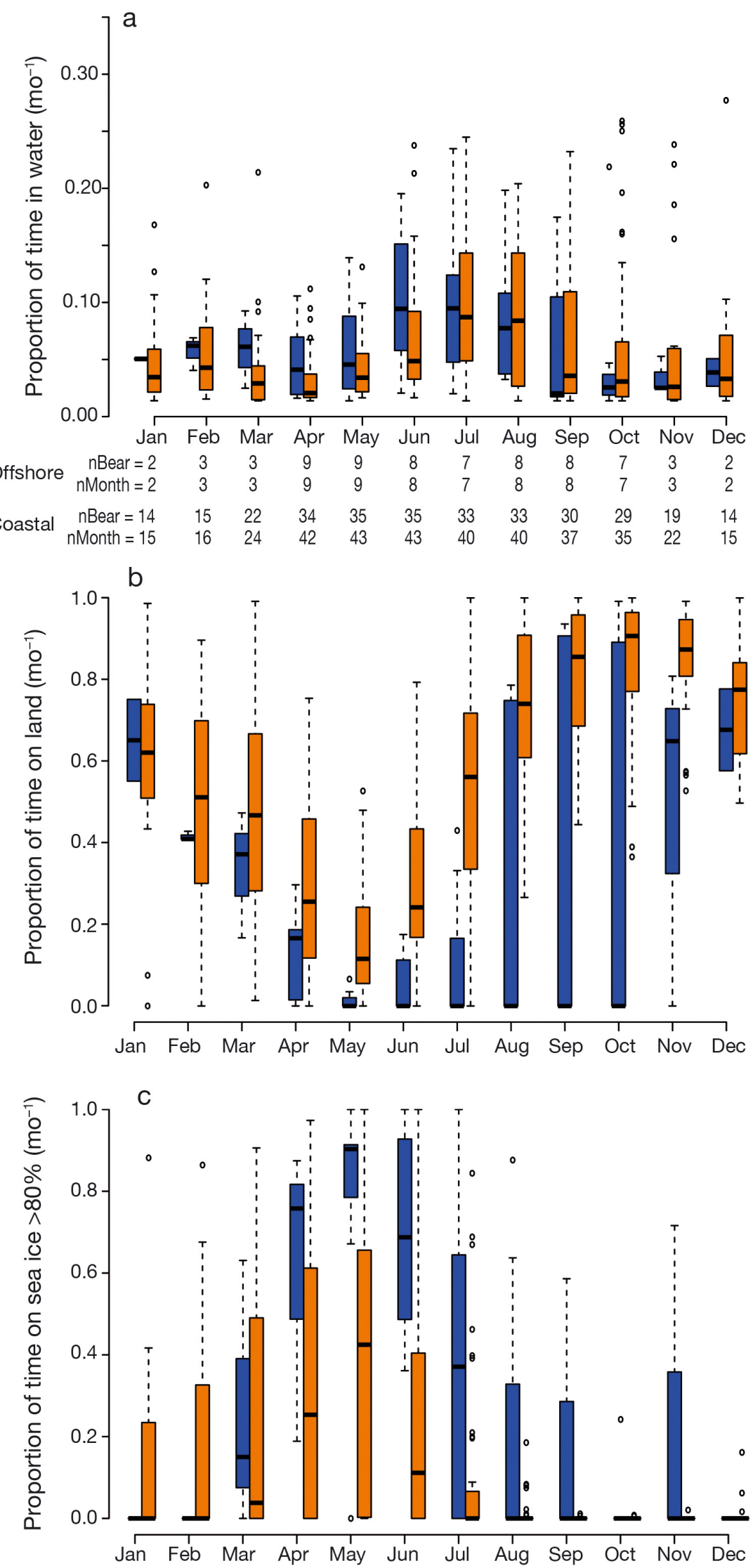

ble from year to year (Mauritzen et al. 2001). Offshore bears could be stranded in large numbers on eastern islands in Svalbard in years when sea ice is scarce. An increase in stranded bears that would have walked north-east in years with sufficient sea ice connection between the islands and the MIZ may cause increased intra-specific competition on land during the icefree period, as not all Barents Sea polar bears fast during the period they are on land, feeding on terrestrial food items (Tartu et al. 2016, Bourgeon et al. 2017). For some bears, bearded seals Erignathus barbatus may also be important in summer (Derocher et al. 2002, Iversen et al. 2013), as they may often rest on pieces of glacier ice, or even on land, thus being more accessible than ringed seals Phoca hispida in the periods with little or no sea ice. However, due to longer ice-free periods, the importance of land-based prey items has increased in the diet of Barents Sea polar bears (Gormezano \& Rockwell 2013, Herreman \& Peacock 2013, Iversen et al. 2013, Prop et al. 2015, Tartu et al. 2016, Stempniewicz 2017).

Parameters linked to energy expenditure such as activity and speedbased FMR estimates were on average $30 \%$ higher for offshore bears compared to coastal ones. This is consistent with the greater rate of movement of the offshore bears. Similar to sea ice drift, ocean currents and winds should be taken into account in the estimation of FMR when bears are swimming in addition to their increased energy

Fig. 5. Monthly proportion of time spent (a) in water, (b) on land and (c) on sea ice with a concentration $>80 \%$ for 46 polar bears carrying instruments including a conductivity switch. Monthly values are aggregates for individual bears (nBear) with polar bears tagged for multiple years contributing to multiple values (nMonth). Boxes are colour coded according to ecotype (blue: offshore; orange: coastal) 

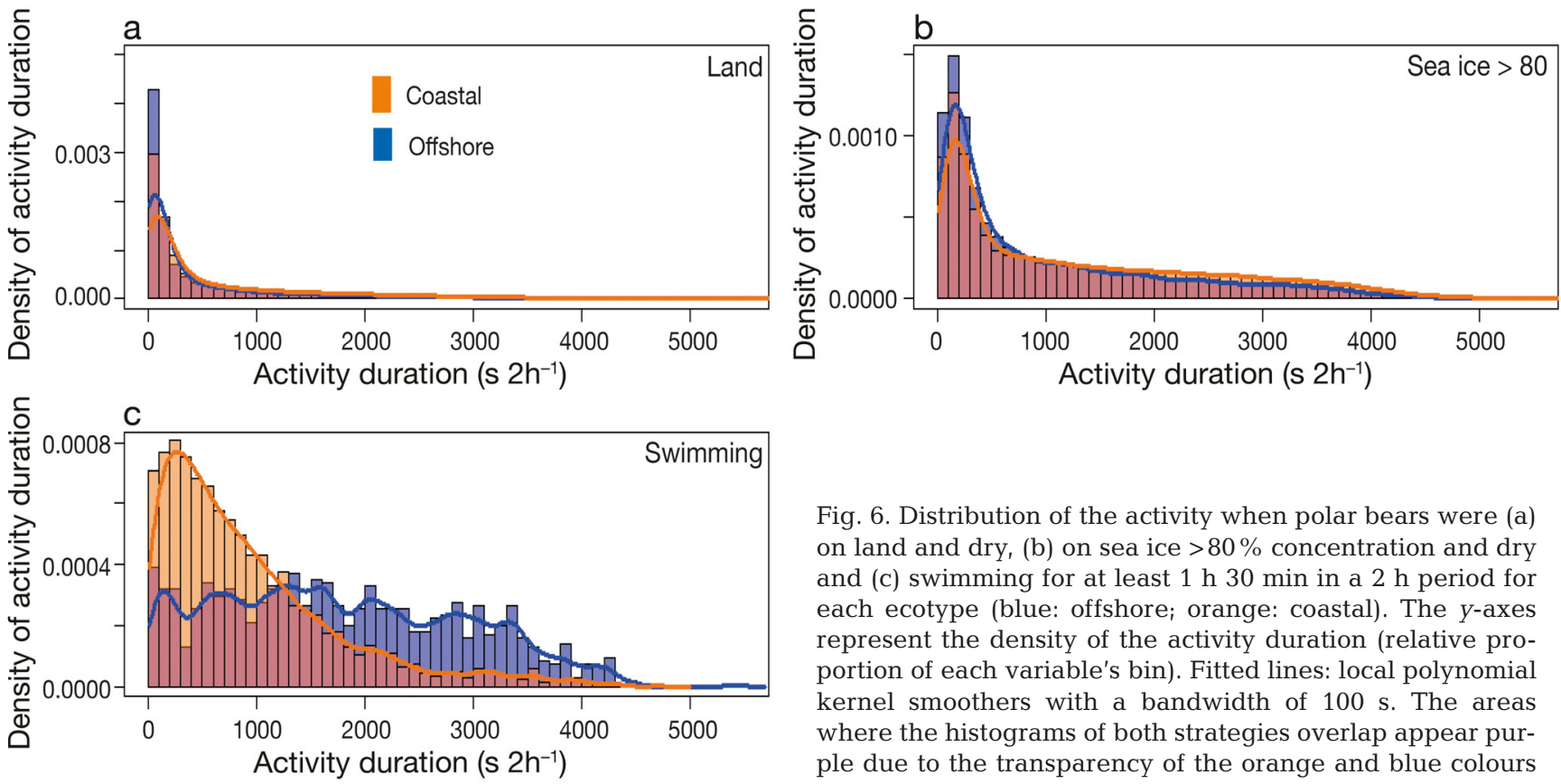

Fig. 6. Distribution of the activity when polar bears were (a) on land and dry, (b) on sea ice $>80 \%$ concentration and dry and (c) swimming for at least $1 \mathrm{~h} 30 \mathrm{~min}$ in a $2 \mathrm{~h}$ period for each ecotype (blue: offshore; orange: coastal). The $y$-axes represent the density of the activity duration (relative proportion of each variable's bin). Fitted lines: local polynomial kernel smoothers with a bandwidth of $100 \mathrm{~s}$. The areas where the histograms of both strategies overlap appear purple due to the transparency of the orange and blue colours
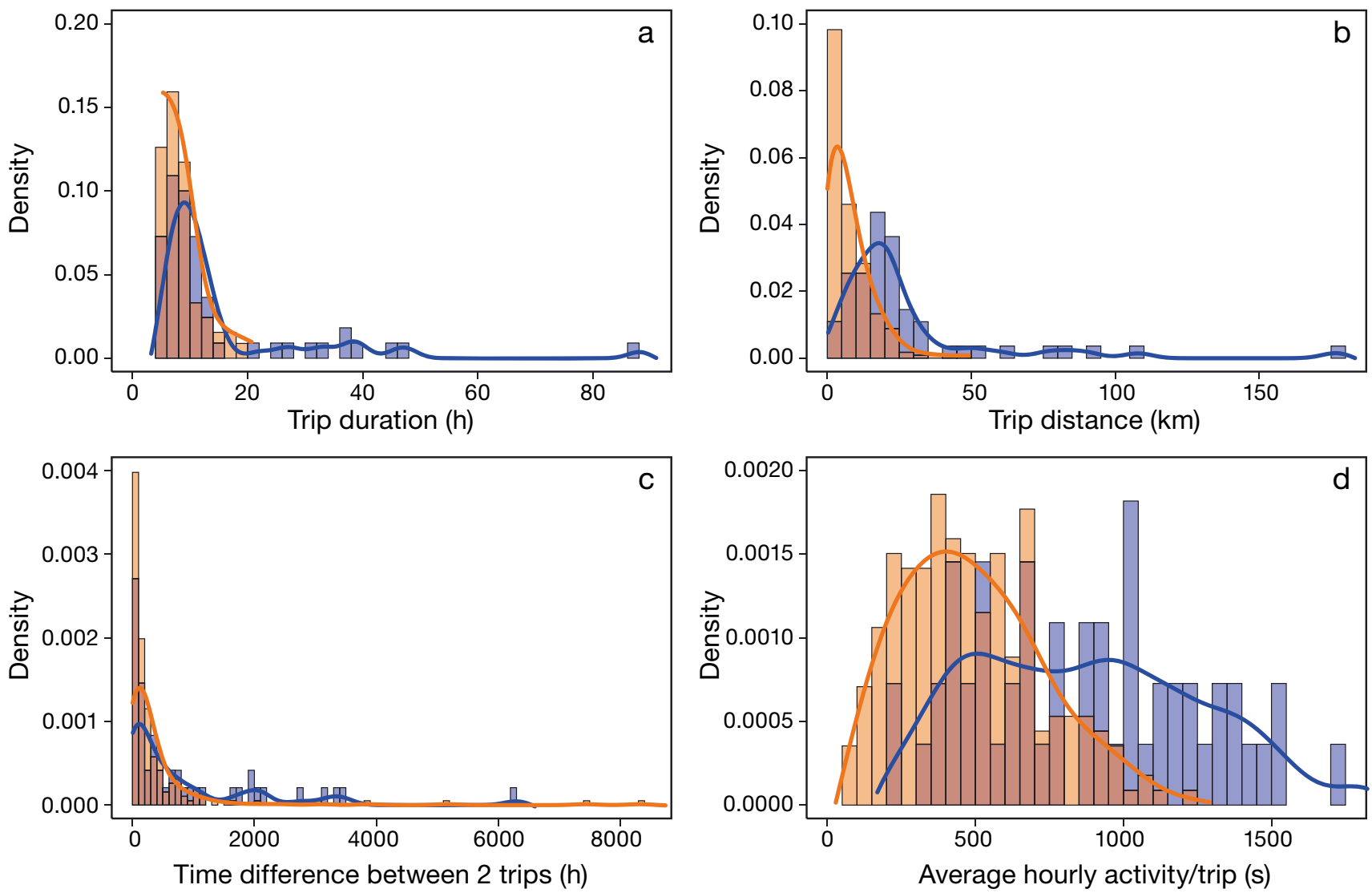

Fig. 7. Frequency distribution of polar bear swimming trips according to ecotype (blue: offshore; orange: coastal); $y$-axes represent the density of each variable (relative proportion of each variable's bin): (a) trip duration; (b) distance swam in a straight line; (c) inter-trip duration; (d) average hourly activity duration during the trips. Fitted lines: local polynomial kernel smoothers with a bandwidth of $2 \mathrm{~h}, 5 \mathrm{~km}, 200 \mathrm{~h}$ and $100 \mathrm{~s}$, respectively. In (a) through (d), areas where histograms of both strategies overlap appear purple due to the transparency of the orange and blue 
expenditure due to heat loss. Taking these variables into account would likely further increase the energy consumption differences between ecotypes, as offshore bears swim longer distances in the open ocean in often rough winds and strong currents (Pagano et al. 2012). Pagano et al. (2018) showed that estimated speed in general explained energy expenditure much better than activity duration. This is likely because the 3D accelerometers measuring activity duration are placed on the neck of the bears, and neck movements are not directly linked to displacement. Captive observations and cameras placed on wild polar bears have shown that they move their neck during a variety of behaviours that do not involve any displacement. This is also shown by the variability in our activity durations at low speed. In addition, attaching the accelerometer to the collar introduces noise in the activity data due to independent movements of the collar (Pagano et al. 2017). Indeed, Pagano et al. (2017) showed that there was a high rate of misclassification in static behaviours with high activity duration despite the high resolution of their activity data $(16 \mathrm{~Hz})$. Our activity data was at a very coarse resolution (sum of the activity within a $2 \mathrm{~h}$ period) and did not allow us to identify specific behaviours.

Seasonality of activity patterns and movement parameters were similar between ecotypes likely due to the phenology of sea ice. Bears moved over larger distances and were generally more active from May through July, corresponding to the period in which they replenish their fat reserves. Coastal bears hunt recently weaned ringed and bearded seals at glacier fronts where this predictable food source is available (Lydersen et al. 2014, Hamilton et al. 2017). Offshore bears are also more active at the MIZ where ringed, bearded and harp seals Pagophilus groenlandica often rest (Freitas et al. 2008, Nordøy et al. 2008, Hamilton et al. 2015). Conversely, bears were less active during the late summer and fall, likely indicating fewer hunting opportunities and therefore a need for conserving energy by reducing unnecessary movements (Ferguson et al. 2001).

Polar bears have much larger HRs than other ursids, and this is partly due to their ability to track productive zones such as the MIZ over large distances by walking or swimming between patches (Pagano et al. 2012, 2018, Pilfold et al. 2017, Lone et al. 2018, Tartu et al. 2018). The proportion of time spent in the water was not overall different between the 2 ecotypes. However, the swimming trips were different. Offshore bears' trips were nearly twice as long in duration and 4 times in distance, and had an overall greater activity level compared to the trips undertaken by coastal bears. Offshore bears swam mainly between coastal areas and the MIZ, whereas coastal bears swam almost exclusively along the coast or across fjords. The latter trips likely encompass several behaviours. Coastal polar bears in Svalbard are known to have a diverse diet including marine algae, sea bird eggs, whale carcasses and seals (Iversen et al. 2013, Prop et al. 2015). These items are found along the shoreline, which might explain why these bears spend a substantial proportion of their aquatic time in the intertidal zone. The activity signals linked to these activities likely include a wide range - from low, for picking up shore-nesting seabird eggs, to high, for diving for marine algae. Bears have been seen performing 'aquatic stalking' of seals hauled out on pieces of ice at glacier fronts, spending large amount of times in the water almost motionless with seldom short bursts of activity (Derocher et al. 2002). Long trips undertaken by offshore bears mainly take place in open water where winds and currents can be strong, which could cause substantially larger activity readings during these trips. These high activity rates combined with thermic losses in the water would make these long trips very energetically costly. This has been shown by an extreme example where a female bear lost $22 \%$ of her body mass after 9 d of continuous swimming (Durner et al. 2011, Pagano et al. 2012).

Despite higher energy expenditure, the offshore ecotype seems to be (at least currently) a profitable strategy, since offshore females were in similar or better condition in the spring compared to coastal bears (Tartu et al. 2018, this study). Offshore bears have year-round access to seals with high energy content that most likely compensates for the increased travel costs (whether walking or swimming) between fragmented suitable hunting habitats in the MIZ. For now, pack ice habitat quality has been described as more optimal compared to land areas, but increased travel costs might offset this advantage in the future (Durner et al. 2011, Pagano et al. 2018). Both polar bear ecotypes are currently affected by habitat changes and will continue to be as their respective habitats change (Hamilton et al. 2017). Neither local nor pelagic bear numbers seems to have decreased in recent years, despite the profound loss of habitat, and this is explained by the Barents Sea population still likely recovering from over-harvesting (Aars et al. 2017). However, the region's carrying capacity is likely to be reduced due to the loss of sea ice and glacier ice and numbers are unlikely to reach pre-harvesting levels (Aars et al. 2017). Coastal 
bears are losing fast-ice habitat in spring and glacial front sea ice as a hunting platform in summer, which causes a decrease in spatial overlap with their main prey (ringed seal) (Hamilton et al. 2017). They may therefore be forced to switch to alternative prey sources, potentially leading to suboptimal caloric intake. Offshore bears are facing different challenges as the MIZ is retreating further away from land where they den. These bears will see an increase in their energetic expenditure due to longer trips at sea in rough weather conditions. This strategy is likely to remain profitable if the density, accessibility and quality of seals is sufficient to cover the bears' increase in energy needs (Tartu et al. 2018). Alternatively, offshore bears may, to a larger degree, be forced onto land in some years, which is likely to increase competition with coastal bears.

Acknowledgements. This study was financed by the Norwegian Ministry of Climate and Environment (RUS-16/0003) and the Norwegian Polar Institute. The polar bear fieldwork was supported by the World Wildlife Fund. We thank Conrad Helgeland for data base management, and the two anonymous referees for their comments.

\section{LITERATURE CITED}

Aars J, Marques TA, Buckland ST, Andersen M, Belikov S, Boltunov A, Wiig $\varnothing$ (2009) Estimating the Barents Sea polar bear subpopulation size. Mar Mamm Sci 25:35-52

Aars J, Marques TA, Lone K, Andersen M and others (2017) The number and distribution of polar bears in the western Barents Sea. Polar Res 36:1374125

Abraham CL, Sydeman WJ (2006) Prey-switching by Cassin's auklet Ptychoramphus aleuticus reveals seasonal climate-related cycles of Euphausia pacifica and Thysanoessa spinifera. Mar Ecol Prog Ser 313:271-283

Amstrup S (2003) Polar bear, Ursus maritimus. In: Feldhammer GA, Thompson BC, Chapman JA (eds) Wild mammals of North America: biology, management, and conservation, 2nd ed. Johns Hopkins University Press, Baltimore, MD, p 587-610

Auger-Méthé M, Lewis MA, Derocher AE (2016) Home ranges in moving habitats: polar bears and sea ice. Ecography 39: $26-35$

Bitterlin L, Van Buskirk J (2014) Ecological and life history correlates of changes in avian migration timing in response to climate change. Clim Res 61:109-121

* Blévin P, Aars J, Andersen M, Blanchet MA and others (2020) Pelagic vs coastal - key drivers of pollutant levels in Barents Sea polar bears with contrasted space-use strategies. Environ Sci Technol 54:985-995

Bolker BM, Brooks ME, Clark CJ, Geange SW, Poulsen JR, Stevens MHH, White JSS (2009). Generalized linear mixed models: a practical guide for ecology and evolution. Trends Ecol Evol 24:127-135

Bourgeon S, Riemer AK, Tartu S, Aars J, Polder A, Jenssen BM, Routti H (2017) Potentiation of ecological factors on the disruption of thyroid hormones by organo-halo- genated contaminants in female polar bears (Ursus maritimus) from the Barents Sea. Environ Res 158:94-104

*Bomaghin JF, McDonald TL, Stirling I, Derocher AE and others (2015) Polar bear population dynamics in the southern Beaufort Sea during a period of sea ice decline. Ecol Appl 25:634-651

* Calenge C (2006) The package 'adehabitat' for the R software: a tool for the analysis of space and habitat use by animals. Ecol Modell 197:516-519

* Cattet MRL, Caulkett NA, Obbard ME, Stenhouse GB (2002) A body-condition index for ursids. Can J Zool 80: 1156-1161

*Derocher AE, Wiig $\varnothing$, Andersen M (2002) Diet composition of polar bears in Svalbard and the western Barents Sea. Polar Biol 25:448-452

* Derocher AE, Stirling I, Lunn NJ (2004) Polar bears in a warming climate. Integr Comp Biol 44:163-176

* Descamps S, Aars J, Fuglei E, Kovacs KM and others (2017) Climate change impacts on wildlife in a High Arctic archipelago - Svalbard, Norway. Glob Change Biol 23: 490-502

* Durner GM, Whiteman JP, Harlow HJ, Amstrup SC, Regehr EV, Ben-David M (2011) Consequences of long-distance swimming and travel over deep-water pack ice for a female polar bear during a year of extreme sea ice retreat. Polar Biol 34:975-984

* Durner GM, Douglas DC, Albeke SE, Whiteman JP and others (2017) Increased Arctic sea ice drift alters adult female polar bear movements and energetics. Glob Change Biol 23:3460-3473

Falk-Petersen S, Sargent JR, Henderson J, Hegseth EN, Hop H, Okolodkov YB (1998) Lipids and fatty acids in ice algae and phytoplankton from the marginal ice zone in the Barents Sea. Polar Biol 20:41-47

Ferguson SH, Taylor MK, Born EW, Rosing-Asvid A, Messier F (2001) Activity and movement patterns of polar bears inhabiting consolidated versus active pack ice. Arctic 54: 49-54

* Frair JL, Fieberg J, Hebblewhite M, Cagnacci F, DeCesare N, Pedrotti L (2010) Resolving issues of imprecise and habitat-biased locations in ecological analyses using GPS telemetry data. Philos Trans R Soc B 365:2187-2200

Freitas C, Kovacs KM, Ims RA, Lydersen C (2008) Predicting habitat use by ringed seals (Phoca hispida) in a warming Arctic. Ecol Modell 217:19-32

Freitas C, Kovacs KM, Andersen M, Aars J and others (2012) Importance of fast ice and glacier fronts for female polar bears and their cubs during spring in Svalbard, Norway. Mar Ecol Prog Ser 447:289-304

*Griffen BD (2018) Modeling the metabolic costs of swimming in polar bears (Ursus maritimus) Polar Biol 41: 491-503

* Gormezano LJ, Rockwell RF (2013) What to eat now? Shifts in polar bear diet during the ice-free season in western Hudson Bay. Ecol Evol 3:3509-3523

*Hamilton CD, Lydersen C, Ims RA, Kovacs KM (2015) Predictions replaced by facts: a keystone species' behavioural responses to declining arctic sea-ice. Biol Lett 11: 20150803

*Hamilton CD, Lydersen C, Ims RA, Kovacs KM (2016) Coastal habitat use by ringed seals Pusa hispida following a regional sea-ice collapse: importance of glacial refugia in a changing Arctic. Mar Ecol Prog Ser 545: 261-277

Hamilton CD, Kovacs KM, Ims RA, Aars J, Lydersen C 
(2017) An Arctic predator-prey system in flux: climate change impacts on coastal space use by polar bears and ringed seals. J Anim Ecol 86:1054-1064

Herreman J, Peacock E (2013) Polar bear use of a persistent food subsidy: insights from non-invasive genetic sampling in Alaska. Ursus 24:148-163

*Hoffmann AA, Sgrò CM (2011) Climate change and evolutionary adaptation. Nature 470:479-485

* Iversen M, Aars J, Haug T, Alsos IG, Lydersen C, Bachmann L, Kovacs KM (2013) The diet of polar bears (Ursus maritimus) from Svalbard, Norway, inferred from scat analysis. Polar Biol 36:561-571

Johnson DS, London JM, Lea MA, Durban JW (2008) Continuous-time correlated random walk model for animal telemetry data. Ecology 89:1208-1215

Kaleschke L, Lüpkes C, Vihma T, Haarpaintner J, Bochert A, Hartmann J, Heygster G (2001) SSM/I sea ice remote sensing for mesoscale ocean-atmosphere interaction analysis. Can J Rem Sens 27:526-537

Kovacs KM (2018) Bearded seal: Erignathus barbatus. In: Würsig B, Thewissen JGM, Kovacs KM (eds) Encyclopedia of marine mammals, $3^{\text {rd }}$ edn. Academic Press, London, p 83-86

Kovacs KM, Lydersen C, Overland JE, Moore SE (2011) Impacts of changing sea-ice conditions on Arctic marine mammals. Mar Biodivers 41:181-194

Lavielle M (2005) Using penalized contrasts for the changepoint problem. Signal Processing 85:1501-1510

* Lippold A, Bourgeon S, Aars J, Andersen M and others (2019) Temporal trends of persistent organic pollutants in Barents Sea polar bears (Ursus maritimus) in relation to changes in feeding habits and body condition. Environ Sci Technol 53:984-995

Lone K, Aars J, Ims RA (2013) Site fidelity of Svalbard polar bears revealed by mark-recapture positions. Polar Biol 36:27-39

Lone K, Kovacs KM, Lydersen C, Fedak M, Andersen M, Lovell P, Aars J (2018) Aquatic behaviour of polar bears (Ursus maritimus) in an increasingly ice-free Arctic. Sci Rep 8:9677

* Lydersen C, Assmy P, Falk-Petersen S, Kohler J and others (2014) The importance of tidewater glaciers for marine mammals and seabirds in Svalbard, Norway. J Mar Syst 129:452-471

*Mauritzen M, Derocher AE, Wiig Ø (2001) Space-use strategies of female polar bears in a dynamic sea ice habitat. Can J Zool 79:1704-1713

Mauritzen M, Derocher AE, Wiig $\varnothing$, Belikov SE, Boltunov AN, Hansen E, Garner GW (2002) Using satellite telemetry to define spatial population structure in polar bears in the Norwegian and western Russian Arctic. J Appl Ecol 39:79-90

Mohr CO (1947) Table of equivalent populations of North American small mammals. Am Midl Nat 37:223-249

Nilssen KT, Haug T, Potelov V (1991) Field studies of harp seal Phoca groenlandica distribution and feeding ecology in the Barents Sea in September 1990. ICES J Mar Sci 3:1-23

Nordøy ES, Folkow LP, Potelov V, Prischemikhin V, Blix AS (2008) Seasonal distribution and dive behaviour of harp seals (Pagophilus groenlandicus) of the White SeaBarents Sea stock. Polar Biol 31:1119-1135

Obbard ME, Cattet MRL, Howe EJ, Middel KR and others (2016) Trends in body condition in polar bears (Ursus maritimus) from the Southern Hudson Bay subpopula- tion in relation to changes in sea ice. Arct Sci 2:15-32

* Olsen GH, Mauritzen M, Derocher AE, Sørmo EG, Skaare JU, Wiig $\varnothing$, Jenssen BM (2003) Space-use strategy is an important determinant of PCB concentrations in female polar bears in the Barents Sea. Environ Sci Technol 37:4919-4924

*Pagano AM, Williams TM (2019) Estimating the energy expenditure of free-ranging polar bears using tri-axial accelerometers: a validation with doubly labeled water. Ecol Evol 9:4210-4219

*Pagano AM, Durner GM, Amstrup SC, Simac KS, York GS (2012) Long-distance swimming by polar bears (Ursus maritimus) of the southern Beaufort Sea during years of extensive open water. Can J Zool 90:663-676

Pagano AM, Rode KD, Cutting A, Owen MA and others (2017) Using tri-axial accelerometers to identify wild polar bear behaviors. Endang Species Res 32:19-33

Pagano AM, Durner GM, Rode KD, Atwood TC and others (2018) High-energy, high-fat lifestyle challenges an Arctic apex predator, the polar bear. Science 359:568-572

* Patin R, Etienne MP, Lebarbier E, Benhamou S (2019) segclust2d: bivariate segmentation/clustering methods and tools. R package version 0.2.0 https://CRAN.R-project. org/package $=$ segclust $2 \mathrm{~d}$

Perry AL, Low PJ, Ellis JR, Reynolds JD (2008) Climate change and distribution shifts in marine fishes. Science 308:1912-1915

* Pilfold NW, McCall A, Derocher AE, Lunn NJ, Richardson E (2017) Migratory response of polar bears to sea ice loss: to swim or not to swim. Ecography 40:189-199

* Pinheiro J, Bates D, Saikat D, Deepayan S (2018) nlme: linear and nonlinear mixed effect models. R package version 3.1-145 https://CRAN.R-project.org/package=nlme

* Prop J, Aars J, Bårdsen BJ, Hanssen SA and others (2015) Climate change and the increasing impact of polar bears on bird populations. Front Ecol Evol 3:33

R core Team (2019) R: a language and environment for statistical computing. R Foundation for Statistical Computing, Vienna

Reed TE, Schindler DE, Waples RS (2011) Interacting effects of phenotypic plasticity and evolution on population persistence in a changing climate. Conserv Biol 25:56-63

* Regehr EV, Laidre KL, Akçakaya HR, Amstrup SC and others (2016) Conservation status of polar bears (Ursus maritimus) in relation to projected sea-ice declines. Biol Lett 12:20160556

Rode KD, Amstrup SC, Regehr EV (2010) Reduced body size and cub recruitment in polar bears associated with sea ice decline. Ecol Appl 20:768-782

Schmidt-Nielsen K (1997) Animal physiology: adaptation and environment, $5^{\text {th }}$ edn. Cambridge University Press, Cambridge

Spreen G, Kaleschke L, Heygster G (2008) Sea ice remote sensing using AMSR-E 89-GHz channels. J Geophys Res 113:C02S03

Stempniewicz L (2017) Polar bears observed climbing steep slopes to graze on scurvy grass in Svalbard. Polar Res 36: 1326453

Stern HL, Laidre KL (2016) Sea-ice indicators of polar bear habitat. Cryosphere 10:2027-2041

Stirling I, Derocher AE (2012) Effects of climate warming on polar bears: a review of the evidence. Glob Change Biol 18:2694-2706

Stirling I, Parkinson CL (2006) Possible effects of climate warming on selected populations of polar bears (Ursus maritimus) in the Canadian Arctic. Arctic 59:261-275 
Stirling I, Spencer C, Andriashek D (1989) Immobilization of polar bears (Ursus maritimus) with Telazol ${ }^{\circledR}$ in the Canadian Arctic. J Wildl Dis 25:159-168

Tartu S, Bourgeon S, Aars J, Andersen M and others (2016) Geographical area and life history traits influence diet in an Arctic marine predator. PLOS ONE 11:e0155980

Tartu S, Aars J, Andersen M, Polder A and others (2018) Choose your poison-space-use strategy influences pollutant exposure in Barents Sea polar bears. Environ Sci Technol 52:3211-3221

Tschudi M, Meier WN, Stewart JS, Fowler C, Maslanik J (2019) Polar Pathfinder Daily 25 km EASE-Grid Sea Ice
Motion Vectors, Version 4. NASA National Snow and Ice Data Center Distributed Active Archive Center. https:// doi.org/10.5067/INAWUWO7QH7B (Accessed 15 October 2019)

Ware JV, Rode KD, Bromaghin JF, Douglas DC and others (2017) Habitat degradation affects the summer activity of polar bears. Oecologia 184:87-99

*Wood SN (2003) Thin plate regression splines. J R Stat Soc Ser B Stat Methodol 65:95-114

* Zeyl E, Aars J, Ehrich D, Wiig Ø (2009) Families in space: relatedness in the Barents Sea population of polar bears (Ursus maritimus). Mol Ecol 18:735-749

Appendix 1. Detailed description of the structure of the missing data

\section{Time differences between 2 consecutive GPS locations}

Our instruments were programmed to transmit every $2 \mathrm{~h}$ with no duty cycle. We recorded 284496 GPS locations between 2011 and 31 October 2018 from 116 collars and 84 female polar bears. The average time difference between 2 consecutive locations was $3.0 \pm 8.0 \mathrm{~h}$ with a median of $2 \mathrm{~h}$; $90 \%$ of the data had a gap of $\leq 4.0 \mathrm{~h}$ and $99 \%$ of the data had a gap of $\leq 16 \mathrm{~h}$. The maximum data gap was $560 \mathrm{~h}$ (= $23 \mathrm{~d}$ ). The structure of these missing data was similar for both ecotypes (Fig. A1).

\section{Structure of missing data for coastal bears}

The average time difference between 2 consecutive GPS locations for coastal bears was $2.7 \pm 3.6 \mathrm{~h}$, with a median of $2 \mathrm{~h}$ and a maximum gap of $474 \mathrm{~h}(=20 \mathrm{~d})$. In this data set, $99 \%$ of the data had a gap $<12 \mathrm{~h}$. Out of the remaining $1 \%$ (with gaps greater than $12 \mathrm{~h}$ ), the average gap was $24 \pm$ $25 \mathrm{~h}$ with a median of $16 \mathrm{~h}$, and $98 \%$ of these gaps were $\leq 92 \mathrm{~h}$ (= $3.8 \mathrm{~d}$ ) (Fig. A2). We had 21 instances where gaps were $>128 \mathrm{~h}(=5 \mathrm{~d})$.

\section{Structure of missing data for offshore bears}

The average time difference between 2 consecutive GPS locations for offshore bears was $3.2 \pm 5.3 \mathrm{~h}$ with a median of $2 \mathrm{~h}$ and a maximum gap of $560 \mathrm{~h}(=23 \mathrm{~d})$. In this data set, $99 \%$ of the data had a gap of $<16 \mathrm{~h}$. Out of the remaining $1 \%$ (with gaps $>16 \mathrm{~h}$ ), the average gap was $33 \pm 35 \mathrm{~h}$ with a median of $24 \mathrm{~h}$, and $98 \%$ of these gaps were $\leq 123 \mathrm{~h}$ (= $5 \mathrm{~d}$ ) (Fig. A3). We had 13 instances where gaps were $>128 \mathrm{~h}(=5 \mathrm{~d})$.

The number of 'crawl' predicted locations was also minimal when considering the data set. It corresponded to $3.9 \%$ of the daily locations for the coastal and $7.0 \%$ for the offshore data set.

\section{Number of days per month}

The minimum number of days per month with data that was used to calculate daily HR was set at 5 in order to retain the maximum amount of data and to match the cutoff used by Lone et al. (2018). The range of transmitted data was 1-31 $\mathrm{d} \mathrm{mo}^{-1}$ with $90 \%$ of the months containing at least $21 \mathrm{~d}$ of data and an average of $28.3 \mathrm{~d} \mathrm{mo}^{-1}$ (Fig. A4).
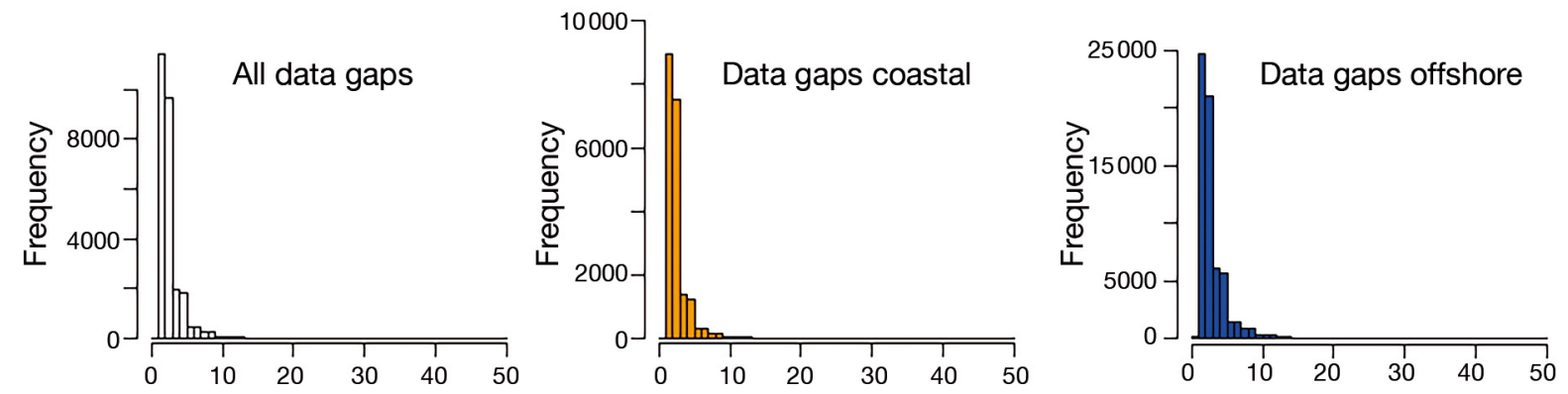

Time interval between 2 GPS locations (h)

Fig. A1. Structure of the missing data for the whole data set, for coastal polar bears and offshore bears. Note that the histograms are truncated at $50 \mathrm{~h}$ to improve readability 
Appendix 1 (continued)

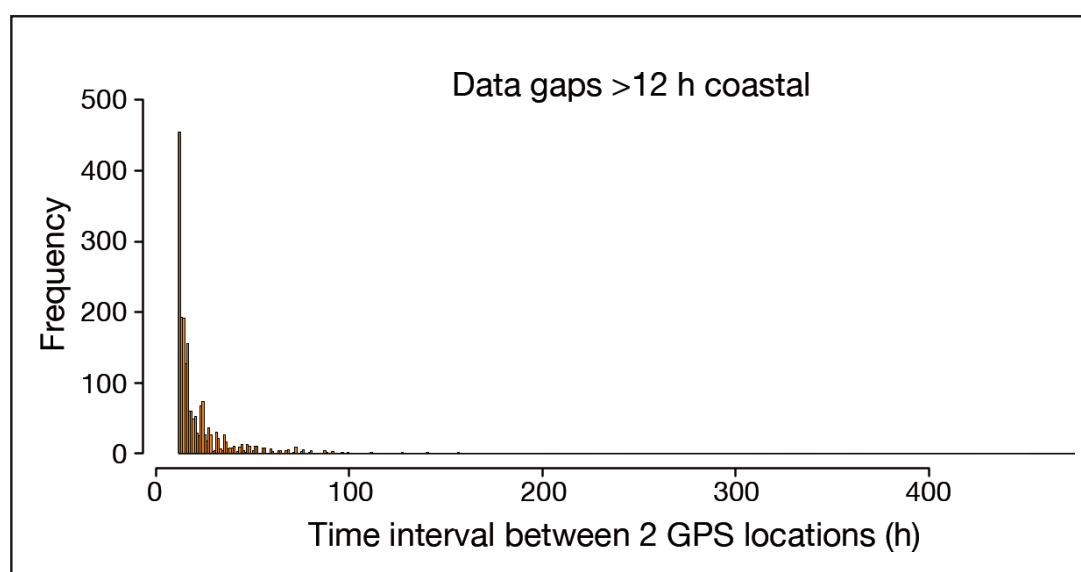

Fig. A2. Time differences between 2 consecutive GPS locations representing the upper percentile ( $>12 \mathrm{~h}$ ) of the data set for coastal polar bears

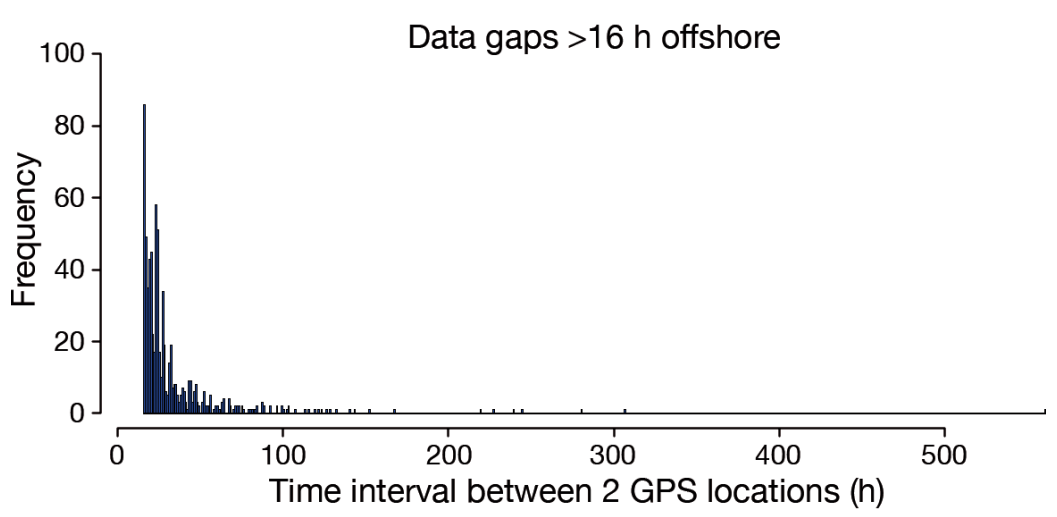

Fig. A3. Time differences between 2 consecutive GPS locations representing the upper percentile $(>16 \mathrm{~h}$ ) of the data set for offshore polar bears

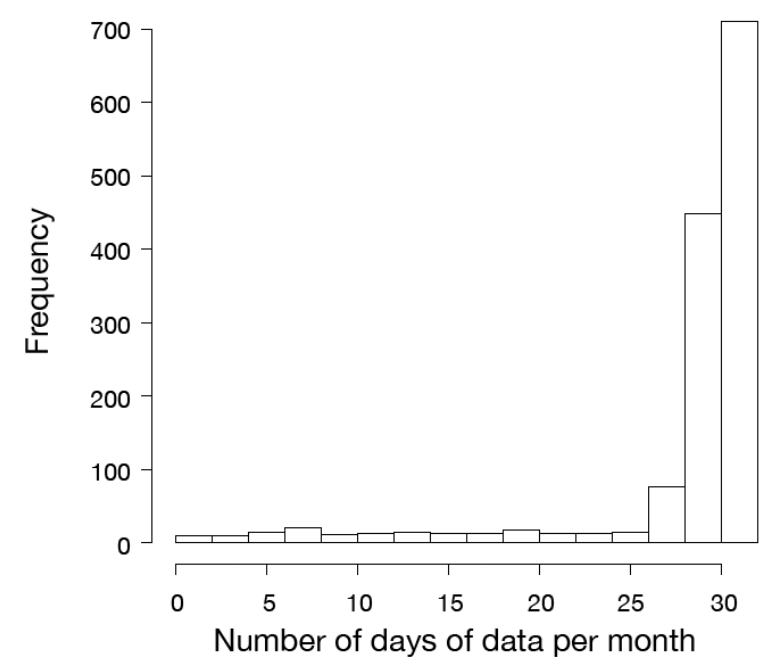

Fig. A4. Number of days per month with data on polar bear locations including the whole data set 